\title{
Chiral Auxiliary-Mediated Enantioenrichment of $( \pm)$-Ibuprofen, under Steglich conditions, with Secondary Alcohols derived from $(R)$-Carvone
}

\author{
Marcela Amongero, Damian Visnovezky and Teodoro S. Kaufman* \\ Instituto de Química Rosario (IQUIR, CONICET-UNR) and Facultad de Ciencias Bioquímicas y \\ Farmaceuticas, Universidad Nacional de Rosario, Suipacha 531, S2002LRK Rosario, Argentina
}

\begin{abstract}
A síntese de uma série de álcoois secundários derivados da $(R)$-carvona, assim como o curso estereoquímico da esterificação destes derivados com ( \pm )-ibuprofeno é apresentada. O composto comercial racêmico foi transformado nos respectivos ésteres diastereoisoméricos através do acoplamento mediado por DCC/DMAP, fornecendo o par de diastereoisômeros derivados de $(S)$ - ou $(R)$-ibuprofeno em relação até 5.7:1, dependendo do tipo de auxiliar quiral empregado.
\end{abstract}

The synthesis of a series of chiral secondary alcohols derived from $(R)$-carvone, and the stereochemical outcome of their reaction with $( \pm)$-ibuprofen, is reported. The racemic drug was transformed into the corresponding diastereomeric esters mediated by DCC/DMAP, affording up to 5.7:1 diastereomeric ratios of the esters derived from either $(S)$ - or $(R)$-ibuprofen, depending on the type of chiral auxiliary employed.

Keywords: ibuprofen, carvone, Steglich esterification, chiral auxiliaries, chiral secondary alcohols

\section{Introduction}

During the past two decades, the preparation of optically active drugs has received considerable attention both, from academics and industry. The reasons behind this interest are threefold, including the medical benefit from using a single chemical entity, the changing pharmaceutical regulations, which now require the development of optically active drugs as single stereoisomers, and also advances in strategies for the synthesis of optically pure compounds, which facilitated the task. ${ }^{1}$

Ibuprofen (1, Figure 1) is a non-steroidal antiinflammatory agent of the class of the $\alpha$-arylpropionic acids, which also includes flurbiprofen (2, Figure 1), fenoprofen (3, Figure 1), ketoprofen (4, Figure 1) and naproxen (5, Figure 1), amongst its most prominent members. The drug is marketed mostly as the racemate despite that it has been shown that the $(S)$-enantiomer is the main responsible for the therapeutic effect. The pure enantiomer is also available, being prescribed only for certain specific conditions. ${ }^{2}$

It has been demonstrated that $(R)$-ibuprofen as well as its congeners can be stereoselectively interconverted in vivo

*e-mail: kaufman@iquir-conicet.gov.ar into their active enantiomers through a thioester-mediated epimerization process which involves the Co-enzyme A (CoA). ${ }^{3}$ However, these acyl-CoA thioester derivatives are chemically reactive and may become involved in a transacylation reactions with endogenous nucleophiles, leading to covalent binding of the drug to proteins, the clinical consequences of which relate to the toxicity of this pharmaceutically active ingredient. ${ }^{4}$ It is also suspected that the acyl-CoA intermediate derived from $(R)$-ibuprofen may be responsible for the formation of mixed glyceryl esters, which once deposited in fatty tissue could cause unknown long-term effects, transforming $(R)$-ibuprofen into a pharmacological uncertainty. ${ }^{5}$

Therefore, the selective preparation of $(S)$-ibuprofen has been the subject of intense research and numerous stereoselective chemical approaches have been explored for that purpose. ${ }^{6}$ In addition, resolutions of the racemate by means of crystallization of diastereomeric salts, ${ }^{7}$ as well as chemoenzimatic transformations including esterificacion, trans-esterification, ${ }^{8}$ enantioselective hydrolysis of esters, ${ }^{9}$ amides ${ }^{10}$ and nitriles ${ }^{11}$ and other enzyme-mediated strategies, ${ }^{12}$ and a yeast-mediated selective degradation of the unwanted enantiomer, ${ }^{13}$ have also been reported.

Carvone is a naturally-occurring cyclohexylic terpenoid which is isolated from Carum carvi, Anethum graveolans 
<smiles>CC(C)Cc1ccc(C(C)C(=O)O)cc1</smiles><smiles>CC(C(=O)O)c1cccc(C(=O)c2ccccc2)c1</smiles>

ketoprofen (4)

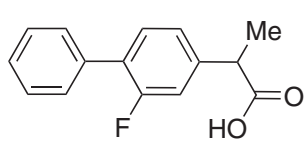

flurbiprofen (2)<smiles>COc1ccc2cc(C(C)C(=O)O)ccc2c1</smiles>

naproxen (5)<smiles>CC(C(=O)O)c1cccc(Oc2ccccc2)c1</smiles>

fenoprofen (3)<smiles>C=C(C)C1CC=C(C)C(=O)C1</smiles>

R-carvone (6)

Figure 1. Chemical structures of ( \pm )-ibuprofen (1), other relevant $\alpha$-arylpropionic acid type non-steroidal anti-inflammatory agents (2-5) and $R$-carvone (6).

and Mentha spicata, being available in both of its enantiomeric forms. It has been extensively employed as building block in organic synthesis. ${ }^{14}$ Interestingly, however, the use of carvone derivatives as chiral auxiliaries has only few and scattered precedents. ${ }^{15}$

The chiral auxiliary-mediated dynamic kinetic resolution of $\alpha$-substituted carboxylic acids has been recently recognized as an approach towards the preparation of enantioenriched $\alpha$-aminoacids, as well as their $\alpha$-mercapto-, $\alpha$-halo- and $\alpha$-hydroxy- congeners. This is an effective alternative, provided configurational lability can be induced at the stereogenic $\alpha$-carbonyl center. ${ }^{16}$

Recently, Amoroso and coworkers ${ }^{17,18}$ reported the preparation of different $\alpha$-arylpropionic acids in their enantioenriched forms, by using lactamide-type chiral auxiliaries. The diastereomeric mixtures of the corresponding lactamic esters were obtained in good yields and reasonable diastereoselectivities depending upon the solvent and chiral auxiliary used. Therefore, here we wish to report the synthesis of chiral secondary alcohols derived from $(R)$-carvone $(\mathbf{6}$, Figure 1$)$ and their reaction with racemic ibuprofen under Steglich conditions, ${ }^{19}$ as a stereodivergent entry to enantioenriched mixtures of esters derived from either $(S)$ - or $(R)$-ibuprofen, depending on the type of chiral auxiliary employed.

\section{Results and Discussion}

Three series of secondary alcohols were prepared. In the first one, $(R)$-carvone was submitted to a conjugate addition reaction with thiophenol under thermodynamic conditions, ${ }^{20}$ furnishing thioethers (7a-c, Scheme 1) in 4, 34 and $16 \%$ yield, respectively. On the other hand, reaction with $\mathrm{PhSH}$ and 2-naphthalenethiol under kinetic ${ }^{21}$ conditions afforded sulfides ( $7 \mathbf{a}$ and $\mathbf{8}$, Scheme 1 ) in 60 and 92\% yield, respectively.

The stereochemistry of these products was deduced by comparison with literature data, ${ }^{22}$ analysis of the enhancement of signals in nuclear Overhauser effect (nOe) experiments and examination of their ${ }^{1} \mathrm{H}$ NMR spectra, which revealed that H-3 was considerably more deshielded in 7a $(\delta 3.89$ ppm) than in $\mathbf{7 b}(\delta 2.91 \mathrm{ppm})$ and $\mathbf{7} \mathbf{c}(\delta 3.29 \mathrm{ppm})$, pointing out to a pseudo-axial orientation of the heteroatomic substituent. The preferential generation of $\mathbf{7 a}$ and $\mathbf{8}$ under kinetic conditions is consistent with an axial Michael addition of the thiols from the $\alpha$-face of carvone, driven by stereoelectronic effects, and subsequent protonation of the resulting enolate from the opposite and less hindered $\beta$-face. Compounds $7 \mathbf{b}$ and $\mathbf{7 c}$ may result from the base-mediated equilibration of $\mathbf{7 a}$ under the reaction conditions. ${ }^{23}$

Diastereoselective reduction of ketones $\mathbf{7 a}, \mathbf{7 b}$ and 8 with K-Selectride in anhydrous $\mathrm{THF}^{24}$ from the less encumbered $\beta$-face of their corresponding carbonyl moiety, ${ }^{25}$ provided alcohols $\mathbf{9 a}, \mathbf{9 b}$ and $\mathbf{1 0}$ (Scheme 1) in 58,66 and $56 \%$, respectively.

Thioether $\mathbf{7 b}$ was further elaborated by oxidation with $\mathrm{H}_{2} \mathrm{O}_{2}$ under $\left(\mathrm{NH}_{4}\right)_{6} \mathrm{Mo}_{7} \mathrm{O}_{24}$ catalysis. ${ }^{26}$ This furnished $\mathbf{1 2}$ (Scheme 1) (47\%), 11 (Scheme 1) (5\%) and recovered 7b (30\%) when limiting amounts of the oxidant were employed, and a separable mixture consisting of $\mathbf{1 1}(52 \%)$ and $\mathbf{1 2}(24 \%)$, when a five-fold excess of $\mathrm{H}_{2} \mathrm{O}_{2}$ was used. Next, compounds 11 and 12 were stereoselectively reduced with $\mathrm{K}$-selectride, providing 13 and 14 (Scheme 1) in 45 and 44\% yield, respectively. Low yields were caused by elimination of the sulfur-bearing moiety. However, in an improved approach, the required sulfone-alcohol $\mathbf{1 3}$ was accessed in 60\% yield through the $\left(\mathrm{NH}_{4}\right)_{6} \mathrm{Mo}_{7} \mathrm{O}_{24}$-catalyzed oxidation of alcohol $\mathbf{9 b}$.

For the second series, where the aromatic substituent is directly attached to a cyclohexenic six-membered ring, $(R)$-carvone was subjected to the direct addition of three different Grignard reagents. The procedure stereoselectively furnished alcohols 15a-c (Scheme 2), as result of an antiperiplanar attack of the Grignard reagent with respect to the isopropenyl group. ${ }^{27}$ In turn, these tertiary allylic alcohols were treated with $\mathrm{PCC} / \mathrm{Al}_{2} \mathrm{O}_{3}$, producing an oxidative allylic transposition ${ }^{28}$ to the corresponding 3-phenyl-(S)-carvone derivatives 16a-c (Scheme 2) in yields ranging from 71 to $86 \% .^{29}$ 

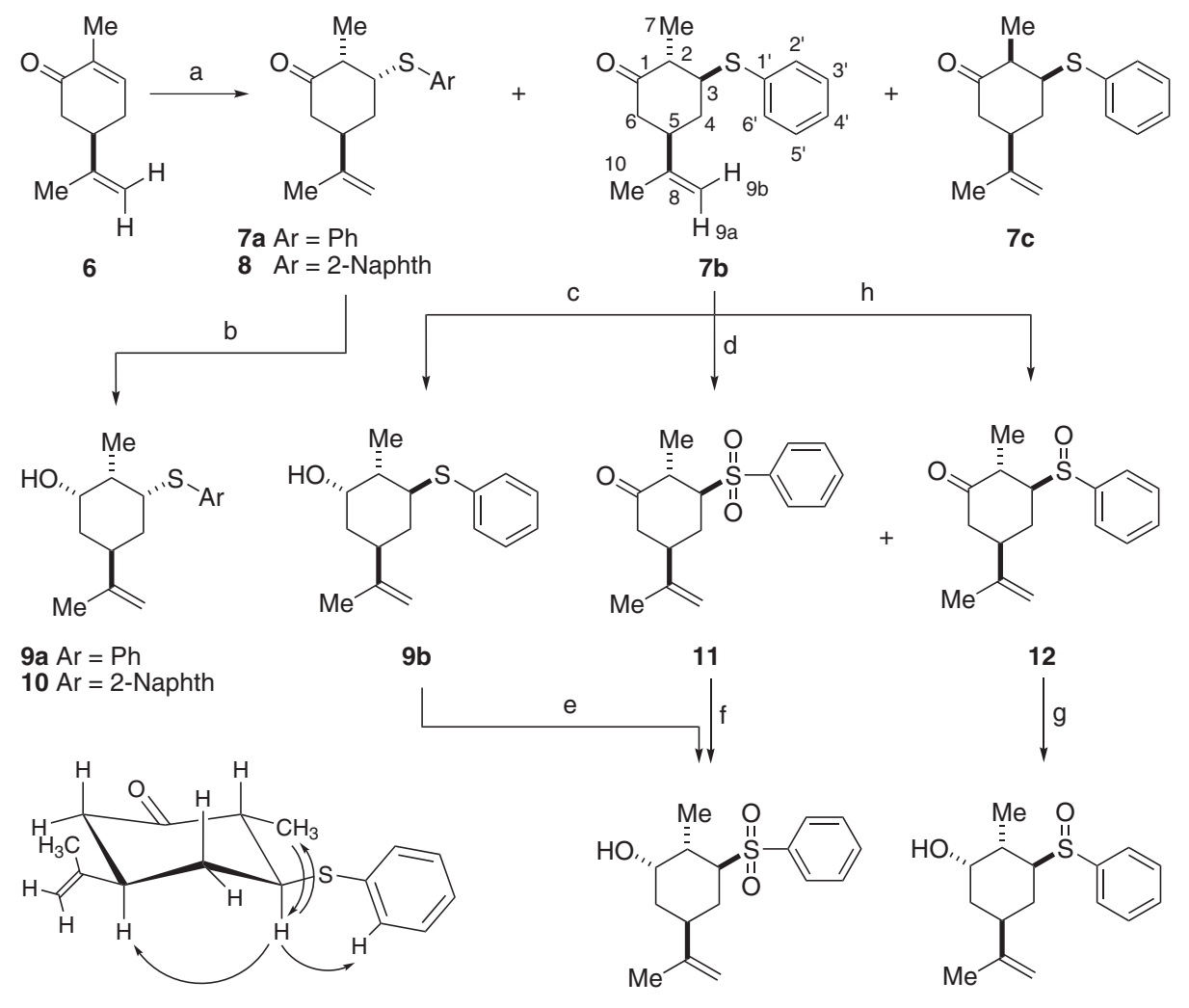

$7 \mathbf{b}$
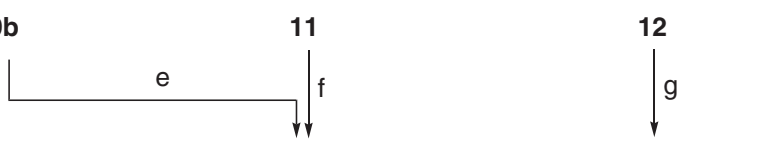

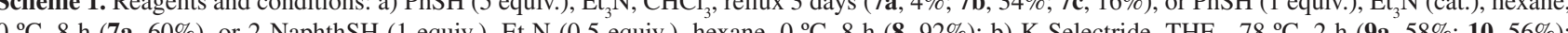
h (7a, 60\%), or 2-NaphthSH (1 equiv.), Et ${ }_{3} \mathrm{~N}\left(0.5\right.$ equiv.), hexane, $0{ }^{\circ} \mathrm{C}, 8 \mathrm{~h}(\mathbf{8}, 92 \%)$; b) $\mathrm{K}-\mathrm{Selectride}, \mathrm{THF},-78{ }^{\circ} \mathrm{C}, 2 \mathrm{~h}(\mathbf{9 a}, 58 \%$; $10,56 \%)$; c) K-Selectride, THF, $-78{ }^{\circ} \mathrm{C}$, overnight $(66 \%)$; d) $\mathrm{H}_{2} \mathrm{O}_{2}(5$ equiv. $),\left(\mathrm{NH}_{4}\right)_{6} \mathrm{Mo}_{7} \mathrm{O}_{24}, \mathrm{EtOH}, 0{ }^{\circ} \mathrm{C}(\mathbf{1 1}, 52 \% ; \mathbf{1 2}, 24 \%)$; e) $\mathrm{H}_{2} \mathrm{O}_{2}\left(5\right.$ equiv.), $\left(\mathrm{NH}_{4}\right) \mathrm{Mo}_{7} \mathrm{O}_{24}$ (cat.), EtOH, $0{ }^{\circ} \mathrm{C}, 24 \mathrm{~h}(60 \%)$; f) $\mathrm{K}-$ Selectride, THF, $-78^{\circ} \mathrm{C}$, overnight $(45 \%)$; g) K-Selectride, THF, $-78^{\circ} \mathrm{C}$, overnight $(44 \%)$; h) $\mathrm{H}_{2} \mathrm{O}_{2}$ ( 1.05 equiv.), $\left(\mathrm{NH}_{4}\right)_{6} \mathrm{Mo}_{7} \mathrm{O}_{24}, \mathrm{EtOH}, 0{ }^{\circ} \mathrm{C}, 3 \mathrm{~h}(\mathbf{1 1}, 5 \% ; \mathbf{1 2}, 47 \%)$.

These ketones were stereoselectively reduced with sodium borohydride in a MeOH-THF mixture, furnishing the secondary allylic alcohols 17a-c (Scheme 2) in 83-94\% yield. Their configuration was determined as $1 S, 5 S$ based on literature precedents ${ }^{30}$ and the results of a nOe experiment, where signal enhancement of H-5 was observed upon irradiation of $\mathrm{H}-1$.

The third group of chiral alcohols was obtained after subjecting $(R)$-carvone to conjugate addition reactions with aryl and 1-naphthyl Grignard reagents in the presence of copper(I) iodide ${ }^{31}$ to which TMSCl was added in order to ensure efficient transformations. ${ }^{32}$
These gave the corresponding silyl enol ether intermediates 18a and 18b (Scheme 3 ) in high yields, as single diastereomers to which the $(3 S, 5 R)$ - configuration was assigned on the basis of literature precedents, ${ }^{33}$ an exhaustive NMR analysis of $\mathbf{1 8 b}$ and knowledge of the role of the isopropenyl group in determining the stereochemistry of the conjugate addition product. The stereochemical result of this reaction is consistent with the outcome of the reductions of ketones $\mathbf{1 6 a - c}$, resulting from a nucleophilic attack anti-periplanar to the bulky isopropenyl group.

In turn, these were desilylated by careful treatment with TBAF in $\mathrm{Et}_{2} \mathrm{O}$ in order to avoid the production of

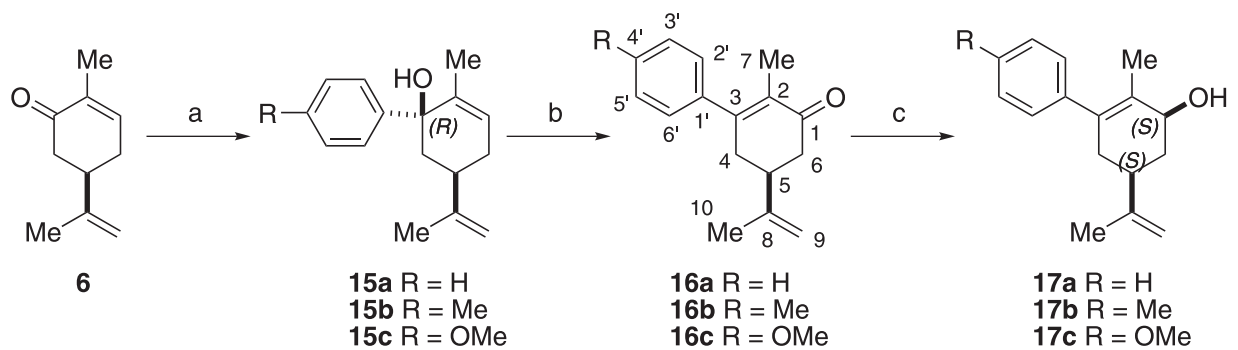

Scheme 2. Reagents and conditions: a) $\mathrm{R}_{-} \mathrm{C}_{6} \mathrm{H}_{4} \mathrm{MgBr}$, THF or Et $\mathrm{O}_{2},-20^{\circ} \mathrm{C}\left(\mathbf{1 5 a}, 75 \%\right.$; 15b, 54\%; 15c, 59\%); b) $\mathrm{PCC} \mathrm{Al}_{2} \mathrm{O}_{3}, \mathrm{CH}_{2} \mathrm{Cl}_{2}, \mathrm{rt}^{(16 a}, 82 \%$; 16b, $86 \% ; \mathbf{1 6 c}, 71 \%)$; c) $\mathrm{NaBH}_{4}, \mathrm{THF}-\mathrm{MeOH}(5: 3), 0{ }^{\circ} \mathrm{C}(\mathbf{1 7 a}, 88 \% ; \mathbf{1 7 b}, 94 \% ; \mathbf{1 7 c}, 83 \%)$. 

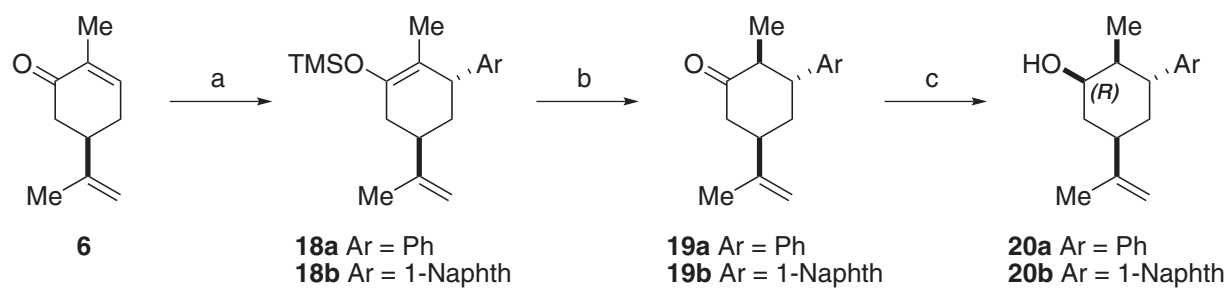

Scheme 3. Reagents and conditions: a) $\mathrm{ArMgBr}$, CuI, TMSCl, THF, $0^{\circ} \mathrm{C}(\mathbf{1 8 a}, 95 \% ; \mathbf{1 8 b}, 96 \%)$; b) $\mathrm{TBAF}, \mathrm{Et}{ }_{2} \mathrm{O}$, rt (19a, 96\%; 19b, 90\%); c) K-Selectride, $\mathrm{THF},-70{ }^{\circ} \mathrm{C}(\mathbf{2 0 a}, 80 \% ; \mathbf{2 0 b}, 80 \%)$.

diastereomeric mixtures at the stereocenter adjacent to the carbonyl, due to the base-catalyzed epimerization of the initial product. ${ }^{34}$ In this process, protonation of the trapped intermediate enolate from the less hindered face anti-periplanar to the C-5 substituent, furnished ketones 19a and 19b (Scheme 3) in 96 and 90\% yields, respectively. Finally, ketones 19a,b were stereoselectively reduced with K-selectride to the corresponding secondary alcohols 20a and 20b (Scheme 3) in $80 \%$ yield.

Interestingly, the stereochemical outcome of the reduction was different from that previously observed with the sulfur-containing alcohols and could be attributed to a different preferred conformation of the starting ketones, where the bulky aryl substituents are located equatorially, flipping the isopropenyl moiety to a pseudo-axial position, thus hindering the approach of the reducing agent from the side of the isopropenyl group.

This speculation was confirmed by nOe experiments on 19a and 19b, which revealed that irradiation of the methylene carbon of the isopropenyl moiety excerted signal enhancement of H-3 (Figure 2). On the other hand, detection of $\mathrm{H}-3$ signal enhancement in 20a upon irradiation of the C-2 methyl group and also of H-9b confirmed that they were located on the same side of the molecule. Furthermore, the axial nature of the hydroxyl group was established from the values of the coupling constants between $\mathrm{H}-1$ and its neighbours in its ${ }^{1} \mathrm{H}$ NMR spectrum $(4.5$ and $5.9 \mathrm{~Hz})$ and its lack of nOe signal enhancement of $\mathrm{H}-1$ upon irradiation of $\mathrm{H}-9 \mathrm{~b}$.

The performance of the chiral auxiliaries was evaluated through their submission to esterification reactions with ( \pm )-ibuprofen, under the conditions described by Steglich, ${ }^{19}$ which employ the DCC-DMAP reagent system as condensing agent.

As shown in Table 1, alcohol 9a provided up to a 28:72 mixture of diastereomeric esters in $89 \%$ combined yield, when the reaction was carried out in $\mathrm{CHCl}_{3}$ at $-50{ }^{\circ} \mathrm{C}$ (entry 1). Furthermore, when the bulkier 2-naphthyl thioether $\mathbf{1 0}$ was used as chiral auxiliary, a slight improvement in the diastereomeric ratio (26:74) was observed, at the expense of a slight decrease in yield of product (entry 10). On the other hand alcohol $\mathbf{9 b}$, a diastereomer of $\mathbf{9 a}$, furnished essentially equimolecular mixtures of diastereomeric esters (entries 4-9), according to NMR and HPLC peak area integration, regardless the solvent and temperature conditions employed.

In an attempt to improve the product diastereomeric ratio, the reactions with the related sulfoxide $\mathbf{1 3}$ and sulfone 14 were explored. However, essentially no chiral induction was observed among the resulting esters (entries 11-14).

Chiral auxiliaries 17a-c gave diastereomeric ratios nearing 2:1 (Table 2), always favouring the same ester which as discussed below, was demonstrated to be that derived from $(S)$-ibuprofen. The best results in terms of chemical and optical yields were obtained with alcohol 17a, when subjected to esterification in toluene at $-20{ }^{\circ} \mathrm{C}$ (entry 3).

When chiral alcohols 20a and 20b were subjected to esterification with $( \pm)$-ibuprofen under Steglich conditions (Table 3), it was observed that the best results were obtained when chloroform was employed as solvent (entries 1,2 and 13) and that the product was enantioenriched in the ester derived from $(R)$-ibuprofen.

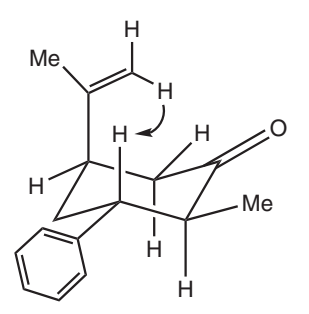

$19 a$

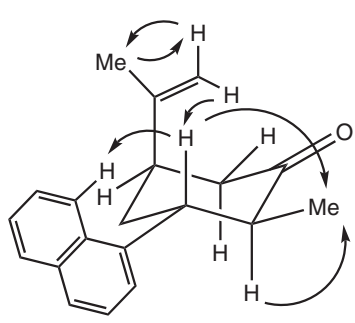

$19 b$

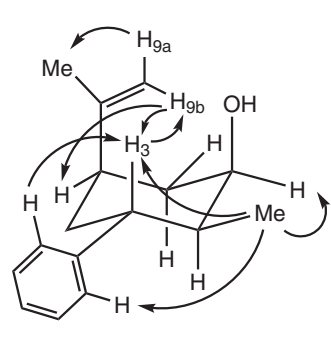

$20 a$

Figure 2. Signal enhancements in the nOe experiments of compounds 19a, 19b and 20a. 
Table 1. Esterification of ( \pm )-ibuprofen with chiral auxiliaries 9a, 9b, 10, 13 and 14

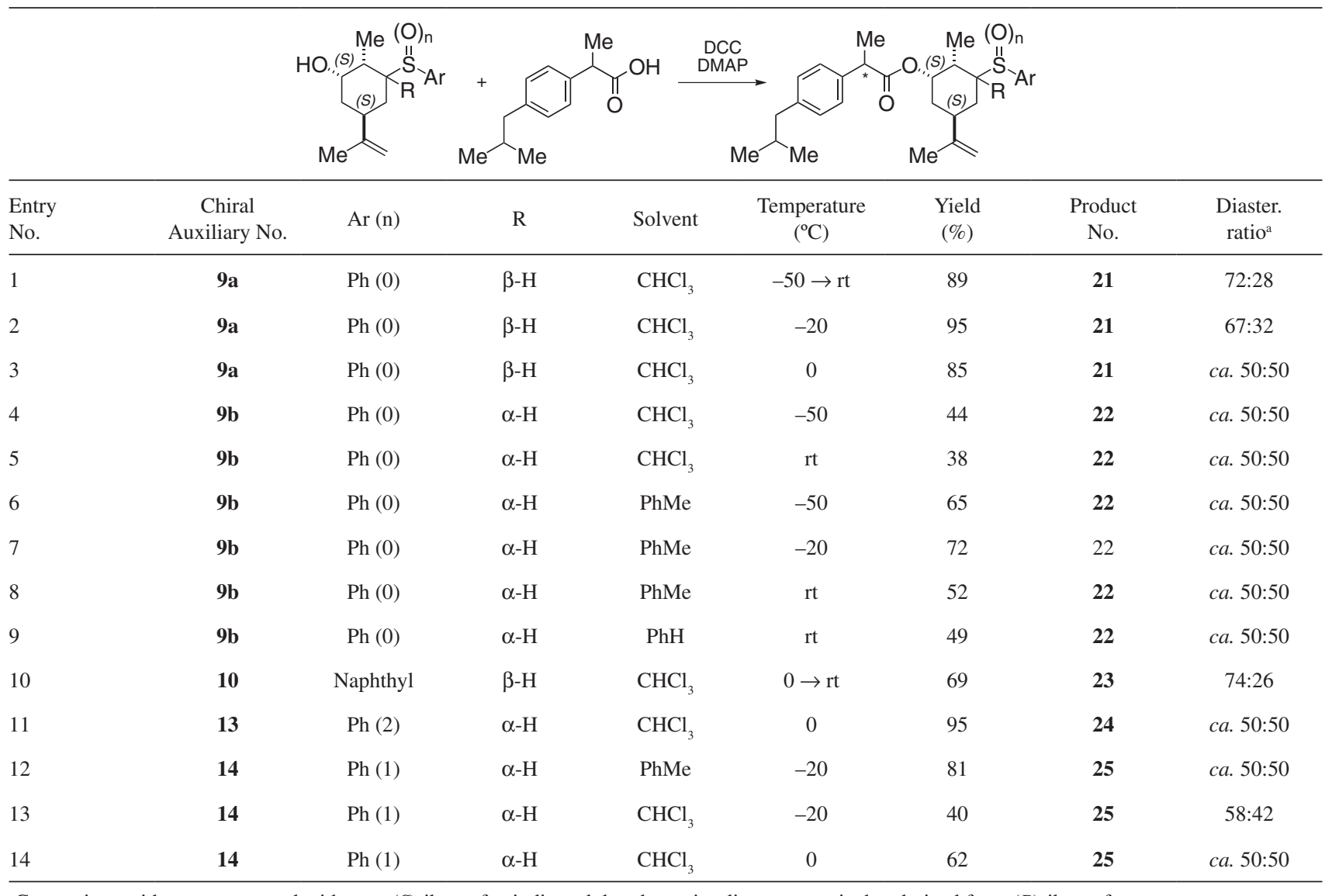

${ }^{\mathrm{a} C o m p a r i s o n ~ w i t h ~ e s t e r s ~ p r e p a r e d ~ w i t h ~ p u r e ~}(S)$-ibuprofen indicated that the major diastereomer is that derived from $(R)$-ibuprofen.

Table 2. Esterification of ( \pm )-ibuprofen with chiral auxiliaries 17a-c

\begin{tabular}{|c|c|c|c|c|c|c|c|}
\hline Entry No. & $\begin{array}{c}\text { Chiral Auxiliary } \\
\text { No. } \\
\end{array}$ & $\mathrm{R}$ & Solvent & $\begin{array}{c}\text { Temperature } \\
\left({ }^{\circ} \mathrm{C}\right)\end{array}$ & $\begin{array}{c}\text { Yield } \\
(\%)\end{array}$ & $\begin{array}{c}\text { Product } \\
\text { No. }\end{array}$ & $R / S^{\mathrm{a}}$ \\
\hline 1 & $17 \mathbf{a}$ & $\mathrm{H}$ & $\mathrm{CHCl}_{3}$ & 0 & 40 & 26 & $42: 58$ \\
\hline 2 & $17 \mathrm{a}$ & $\mathrm{H}$ & $\mathrm{CHCl}_{3}$ & -20 & 70 & 26 & $48: 52$ \\
\hline 3 & $17 a$ & $\mathrm{H}$ & $\mathrm{PhMe}$ & -20 & 81 & 26 & $37: 63$ \\
\hline 4 & $17 a$ & $\mathrm{H}$ & $\mathrm{PhMe}$ & 0 & 32 & 26 & $45: 55$ \\
\hline 5 & $17 a$ & $\mathrm{H}$ & $\mathrm{PhMe}$ & $\mathrm{rt}$ & 72 & 26 & $39: 61$ \\
\hline 6 & $17 \mathrm{~b}$ & $\mathrm{Me}$ & $\mathrm{PhMe}$ & rt & 66 & 27 & $38: 62$ \\
\hline 7 & $17 \mathrm{~b}$ & $\mathrm{Me}$ & $\mathrm{CHCl}_{3}$ & 0 & 21 & 27 & $37: 63$ \\
\hline 8 & $17 \mathrm{~b}$ & $\mathrm{Me}$ & THF & 0 & 39 & 27 & $38: 62$ \\
\hline 9 & $17 \mathrm{c}$ & $\mathrm{MeO}$ & $\mathrm{PhMe}$ & $\mathrm{rt}$ & 90 & 28 & $40: 60$ \\
\hline 10 & $17 \mathrm{c}$ & $\mathrm{MeO}$ & $\mathrm{PhMe}$ & -20 & 85 & 28 & $41: 59$ \\
\hline 11 & $17 \mathrm{c}$ & $\mathrm{MeO}$ & $\mathrm{PhMe}$ & $\mathrm{rt}$ & 72 & 28 & $38: 62$ \\
\hline
\end{tabular}

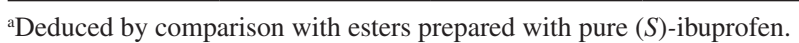


Interestingly, slightly improved diastereomeric ratios were obtained when a five-fold excess of ibuprofen was employed, while changing the order of addition of the reagents, preincubation of a mixture of the acid and the alcohol with activated $4 \AA$ molecular sieves and the addition of triethylamine (entries 3-5) did not improve the diastereomeric ratios of ester products.

In addition, a trend was observed, indicating that the bulkier 1-naphthyl derivative 20b slightly outperformed its congener 20a, probably by leading to a chiral auxiliary with a conformationally more rigid cyclohexyl ring. Under the typical conditions, a ratio of products up to $82: 18$ was observed (entry 13). These levels of enantioenrichment are similar to those previously informed by the group of Amoroso. ${ }^{17}$

For the sake of comparison, the effect of placing a bulkier group near the secondary alcohol was examined with (-)menthol (31, Scheme 4), the esterification of which with ( \pm )-ibuprofen in $\mathrm{CHCl}_{3}$ at $0^{\circ} \mathrm{C}$ gave $55 \%$ of a nearly 1:1 mixture of diasteromeric esters 32 (Scheme 4).

Therefore, the more hindered alcohol 35 (Scheme 4) was synthesized by $\mathrm{K}_{2} \mathrm{Cr}_{2} \mathrm{O}_{7}-\mathrm{H}_{2} \mathrm{SO}_{4}$ oxidation of $\mathbf{3 1}$ to menthone (33, Scheme 4), ${ }^{35}$ followed by a Claisen-Schmidt condensation of the latter with 4-bromobenzaldehyde ${ }^{36}$ to furnish $43 \%$ of $\mathbf{3 4}$ (Scheme 4), which was finally reduced with $\mathrm{NaBH}_{4}$ in $66 \%$ yield. However, Steglich esterification of 35 with ( \pm )-ibuprofen provided a diastereomeric mixture of esters 36 (Scheme 4) in 97\% yield and in a 65:35 $(R / S)$ diastereomeric ratio.

The group of Amoroso has demonstrated that ibuprofen and other $\alpha$-substituted carboxylic acids undergo a dynamic kinetic resolution process when subjected to the Steglich esterification. ${ }^{19}$ As shown in Scheme 5, when an $\alpha$-substituted carboxylic acid (I) reacts with DCC and DMAP, enantiomeric acyl-DMAP derivatives II and III are formed as intermediates. Under these conditions, it has been proposed that the stereogenic center becomes labile and the enantiomeric acyl-DMAP derivatives are thus capable of being interconverted. When a chiral alcohol $(\mathrm{R} * \mathrm{OH})$ is added to the reaction medium, both acyl-DMAP intermediates can react to furnish diastereomeric ester products (IV and $\mathbf{V}$ ). Two main conditions are required for a successful dynamic kinetic resolution. One of them is that interconversion between the acyl-DMAP derivatives II and III should proceed at a faster rate than formation of the ester products and the other is that the acyl-DMAP intermediates should react at very different rates with the chiral auxiliary.

In order to gain further understanding on the studied esterification, a series of esterifications were carried out

Table 3. Esterification of ( \pm )-ibuprofen with chiral auxiliaries 20a and 20b

\begin{tabular}{|c|c|c|c|c|c|c|c|}
\hline & & & & $\begin{array}{l}\text { DCC } \\
\text { DMAP }\end{array}$ & & II & \\
\hline $\begin{array}{l}\text { Entry } \\
\text { No. }\end{array}$ & $\begin{array}{c}\text { Chiral } \\
\text { Auxiliary No. }\end{array}$ & $\mathrm{Ar}$ & Solvent & $\begin{array}{c}\text { Temperature } \\
\left({ }^{\circ} \mathrm{C}\right)\end{array}$ & $\begin{array}{l}\text { Yield } \\
(\%)\end{array}$ & $\begin{array}{l}\text { Product } \\
\text { No. }\end{array}$ & $R / S^{\mathrm{a}}$ \\
\hline 1 & $20 a^{b}$ & $\mathrm{Ph}$ & $\mathrm{CHCl}_{3}$ & $-40 \rightarrow \mathrm{rt}$ & 69 & 29 & $85: 15$ \\
\hline 2 & $20 a^{b}$ & $\mathrm{Ph}$ & $\mathrm{CHCl}_{3}$ & $0 \rightarrow \mathrm{rt}$ & 76 & 29 & $80: 20$ \\
\hline 3 & $20 \mathbf{a}^{\mathrm{c}, \mathrm{d}}$ & $\mathrm{Ph}$ & $\mathrm{CHCl}_{3}$ & - & 96 & 29 & $72: 28$ \\
\hline 4 & $20 \mathbf{a}^{\mathrm{d}, \mathrm{e}}$ & $\mathrm{Ph}$ & $\mathrm{CHCl}_{3}$ & 0 & 84 & 29 & $69: 31$ \\
\hline 5 & $20 a^{e}$ & $\mathrm{Ph}$ & $\mathrm{CHCl}_{3}$ & 0 & 83 & 29 & $61: 39$ \\
\hline 6 & $20 a$ & $\mathrm{Ph}$ & $\mathrm{PhH}$ & $\mathrm{rt}$ & 62 & 29 & $62: 38$ \\
\hline 7 & $20 \mathrm{a}$ & $\mathrm{Ph}$ & $\mathrm{PhH}$ & 40 & 64 & 29 & $65: 35$ \\
\hline 8 & $20 \mathrm{a}$ & $\mathrm{Ph}$ & $\mathrm{CH}_{2} \mathrm{Cl}_{2}$ & 0 & 44 & 29 & $72: 28$ \\
\hline 9 & $20 \mathrm{a}$ & $\mathrm{Ph}$ & $\mathrm{CH}_{2} \mathrm{Cl}_{2}$ & 40 & 69 & 29 & $66: 34$ \\
\hline 10 & $20 \mathrm{a}$ & $\mathrm{Ph}$ & THF & $-40 \rightarrow \mathrm{rt}$ & 64 & 29 & $71: 29$ \\
\hline 11 & $\mathbf{2 0} \mathbf{a}^{\mathrm{d}}$ & $\mathrm{Ph}$ & $\mathrm{PhMe}$ & 0 & 78 & 29 & $62: 38$ \\
\hline 12 & $20 \mathrm{~b}$ & 1-Naphthyl & $\mathrm{PhMe}$ & 0 & 72 & 30 & $73: 27$ \\
\hline 13 & $20 \mathrm{~b}$ & 1-Naphthyl & $\mathrm{CHCl}_{3}$ & $\mathrm{rt}$ & 58 & 30 & $82: 18$ \\
\hline
\end{tabular}

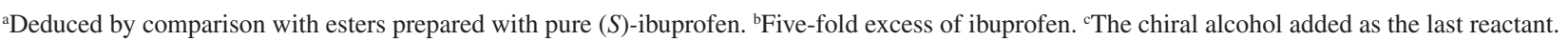
${ }^{\mathrm{d}}$ Pre-incubated with activated $4 \AA$ molecular sieves $(200 \mathrm{mg}) .{ }^{\mathrm{E}} \mathrm{Et}_{3} \mathrm{~N}$ (2 equiv.) were added to the reaction mixture. 
<smiles>CC(C)Cc1ccc(C(C)(C)C(=O)O[C@H]2C[C@H]([N+](=O)[O-])CC[C@H]2C(C)C)cc1</smiles><smiles>[M]C1CCC(C(C)C)C(=O)C1</smiles>

33

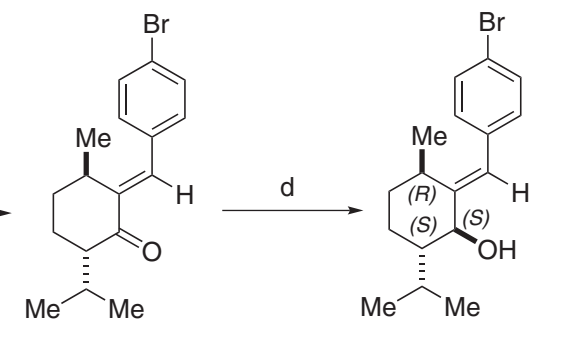

34

35

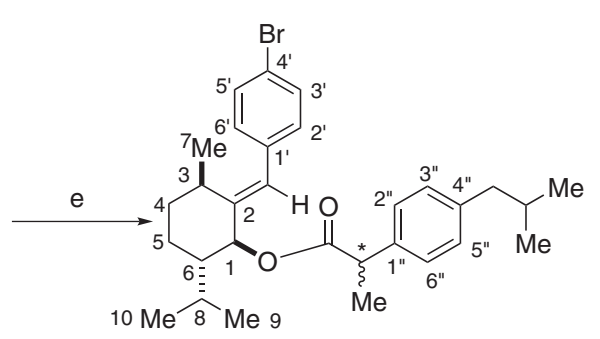

36

Scheme 4. Reagents and conditions: a) DCC (1.0 equiv.), DMAP (1.0 equiv.), ibuprofen (1.0 equiv.), $\mathrm{CHCl}_{3}, 0{ }^{\circ} \mathrm{C}(55 \%)$; b) $\mathrm{K}_{2} \mathrm{Cr}_{2} \mathrm{O}_{7}, \mathrm{H}_{2} \mathrm{SO}_{4}, \mathrm{rt}_{50}{ }^{\circ} \mathrm{C}$ (82\%); c) 4Br- $\mathrm{C}_{6} \mathrm{H}_{4}-\mathrm{CHO}, \mathrm{K}^{\prime} \mathrm{BuO}$, DMSO, $12 \mathrm{~h}$, rt (43\%); d) $\mathrm{NaBH}_{4}$, THF-MeOH, 30 min, $0^{\circ} \mathrm{C}$ (66\%); e) DCC (1.0 equiv.), DMAP (1.0 equiv.), ibuprofen (1.0 equiv.), $\mathrm{CHCl}_{3}, 0^{\circ} \mathrm{C}(97 \%)$.

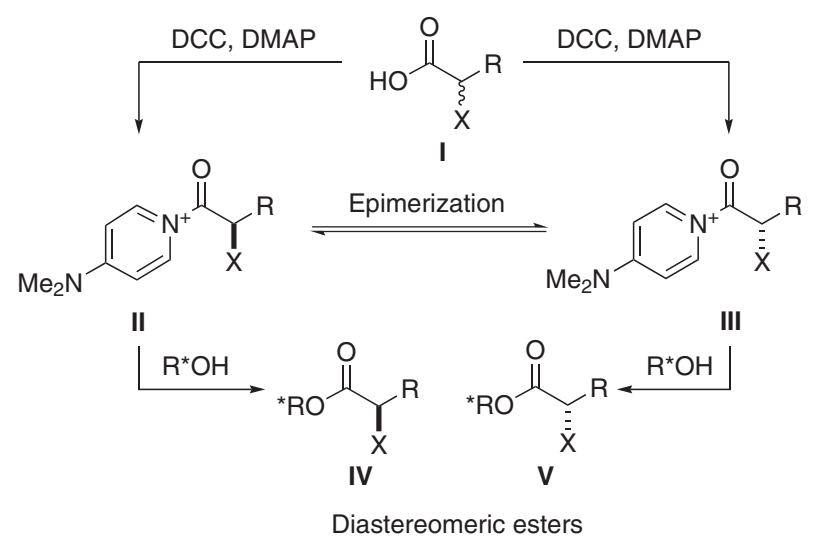

Scheme 5. Proposed mechanism of the DCC-DMAP mediated dynamic kinetic resolution of $\alpha$-substituted carboxylic acids.

with pure $(S)$-ibuprofen. After examination of the products, it was observed that when the reaction was carried out with alcohol 20a the resulting major diastereomers where those carrying the $(R)$-configuration on the ibuprofen $\alpha$-carbonyl stereocenter. On the contrary, when the esterifications where carried out with alcohols 17a-c, the prevailing diastereomers were those derived from $(S)$-ibuprofen (Tables 1-3).

However, composition of the mixtures was different from those arising from the racemic acid, pointing out to poor compliance of the studied transformations with the requirements for a successful dynamic kinetic resolution. Particularly, the experiments revealed that interconversion of the enantiomeric acyl-DMAP intermediates is not fast enough, compared with their reaction with the chiral auxiliary, to grant a more optically efficient transformation.

In conclusion, it was demonstrated that secondary alcohols derived from naturally-occurring $(R)$-carvone are able to provide good yields of enantioenriched mixtures of ibuprofen esters, that their performance is similar to that of other chiral alcohols and that depending on the chosen chiral auxiliary, production of $(R)$ - or $(S)$ - ibuprofen derived esters may be favoured.

\section{Experimental}

Melting points were taken on an Ernst Leitz Wetzlar model 350 hot-stage microscope and are reported uncorrected. Specific rotation data were obtained with a Jasco DIP 1000 photopolarimeter, fitted with $1 \mathrm{dm}$ cells. FT-IR spectra were determined employing a Shimadzu Prestige 21 spectrophotometer as solid dispersions in $\mathrm{KBr}$ disks, or as thin films held between $\mathrm{NaCl}$ cells. The ${ }^{1} \mathrm{H}$ and ${ }^{13} \mathrm{C}$ NMR spectra were acquired in $\mathrm{CDCl}_{3}$ in a Bruker Avance spectrometer (300.13 and $75.48 \mathrm{MHz}$ for ${ }^{1} \mathrm{H}$ and ${ }^{13} \mathrm{C}$, respectively), with tetramethylsilane (TMS) as internal standard. The chemical shifts are reported in ppm downfield from TMS and coupling constants $(J)$ are given in Hertz. DEPT 135 and DEPT 90 experiments aided the interpretation and assignment of the fully decoupled ${ }^{13} \mathrm{C}$ NMR spectra. In special cases, 2D-NMR (COSY, HMBC, HMQC and $J$-resolved spectra) and selective nOe experiments were also employed. Pairs of signals marked with “\#”, “ł” or with an asterisk, “*”, as superscripts indicate that their assignments may be exchanged.

The reactions were carried out under dry Nitrogen or Argon atmospheres, employing oven-dried glassware. Reagents were used as received. Dry hexane, benzene and toluene were prepared by distillation from Na-benzophenone ketyl. Anhydrous $\mathrm{CH}_{2} \mathrm{Cl}_{2}$ and $\mathrm{CHCl}_{3}$ were prepared by a $4 \mathrm{~h}$ reflux over $\mathrm{P}_{2} \mathrm{O}_{5}$ followed by distillation. Anhydrous $\mathrm{Et}_{3} \mathrm{~N}$ 
was obtained by distillation, after a $4 \mathrm{~h}$ reflux over $\mathrm{CaH}_{2}$. Anhydrous solvents were stored in dry Young ampoules. In the conventional work-up procedure, the reaction was diluted with brine $(5-10 \mathrm{~mL})$ and the products were extracted with EtOAc $(4-5 \times 20 \mathrm{~mL})$. The combined organic extracts were then washed once with brine $(5 \mathrm{~mL})$, dried over $\mathrm{Na}_{2} \mathrm{SO}_{4}$ and concentrated under reduced pressure. The residue was submitted to flash column chromatography with silica gel $60 \mathrm{H}$. Elution was carried out with hexaneEtOAc mixtures, under positive pressure and employing gradient of solvent polarity techniques.

All new compounds gave single spots on TLC plates run in different hexane-EtOAc and $\mathrm{CH}_{2} \mathrm{Cl}_{2}$-toluene solvent systems. Chromatographic spots were detected by exposure to UV light ( $254 \mathrm{~nm})$, followed by spraying with ethanolic ninhydrin (amines) or with ethanolic $p$-anisaldehyde/ sulfuric acid reagent and careful heating of the plates for improving selectivity.

The diastereomeric esters of ibuprofen were best separated on a Varian ProStar liquid chromatograph fitted with a $250 \times 4.6 \mathrm{~mm} \mathrm{C}-18$ Luna column (Phenomenex, $5 \mu \mathrm{m}$ particle size), using a 80:20 mixture of $\mathrm{MeOH}: 50 \mathrm{mmol} \mathrm{L}^{-1}$ phosphate buffer, pH 5.5 as mobile phase, pumped at

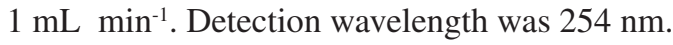

(2S, 3R, 5S)-5-Isopropenyl-2-methyl-3-phenylsulfanylcyclohexanone $7 a$ under kinetic control conditions: Thiophenol (110 mg, $1.0 \mathrm{mmol})$ was added to a stirred solution of $(R)$-carvone $(150 \mathrm{mg}, 1.0 \mathrm{mmol})$ and $\mathrm{Et}_{3} \mathrm{~N}(0.2 \mathrm{~mL})$ in hexane $(3 \mathrm{~mL})$, cooled at $0{ }^{\circ} \mathrm{C}$. The resulting solution was stirred $8 \mathrm{~h}$ at $0{ }^{\circ} \mathrm{C}$ while a white precipitate was formed. The precipitate was separated from the solution, washed twice with hexane $(5 \mathrm{~mL})$ and dried under vacuum, affording $7 \mathbf{a}(156 \mathrm{mg}, 60 \%)$, as a white solid $\mathrm{mp} 62.5-64{ }^{\circ} \mathrm{C}$ (hexane-EtOAc. Lit.: 63-65 $\left.{ }^{\circ} \mathrm{C}^{21}\right) .[\alpha]_{\mathrm{D}}{ }^{25}-100.4\left[\mathrm{c} 1.20, \mathrm{CHCl}_{3}\right.$. Lit.: $.^{21}-91.0$ (c 10, $\mathrm{CH}_{2} \mathrm{Cl}_{2}$ )]. IR (film, $v_{\max } / \mathrm{cm}^{-1}$ ): 2977, 2854, 1700, 1663, 1439, 1290, 1147, 897, 749 and 692. ${ }^{1} \mathrm{H}$ NMR: $\delta$ 1.21 (d, 3H, J 6.8, H-7), 1.65 (bs, 3H, H-10), 1.84 (ddd, $1 \mathrm{H}, J 2.9,11.4$ and $\left.13.8, \mathrm{H}-4_{\mathrm{ax}}\right), 2.06(\mathrm{ddt}, 1 \mathrm{H}, J 2.1,3.8$ and 13.8, $\mathrm{H}-4_{\mathrm{eq}}$ ), 2.28 (ddd, $1 \mathrm{H}, J 1.0,12.5$ and 13.7, H- ${ }_{\mathrm{ax}}$ ), 2.52 (ddd, $1 \mathrm{H}, J 2.1,4.3$ and 13.7, $\mathrm{H}-6_{\mathrm{eq}}$ ), 2.88 (ddq, $1 \mathrm{H}, J 1.1,4.8$ and 6.7, $\mathrm{H}-2$ ), 3.02 (ddt, $1 \mathrm{H}, J 3.8$, 11.4 and $12.5, \mathrm{H}-5$ ), 3.89 (bdt, $1 \mathrm{H}, J 3.5$ and $4.8, \mathrm{H}-3$ ), 4.70 (bs, 1H, H-9b), 4.76 (bs, 1H, H-9a), 7.21-7.32 (m, $3 \mathrm{H}, \mathrm{H}-3$ ', $\mathrm{H}-4$ ' and $\left.\mathrm{H}-5^{\prime}\right)$ and 7.38-7.42 (m, 2H, H-2' and H-6'). ${ }^{13} \mathrm{C}$ NMR: $\delta 12.7$ (C-7), 20.8 (C-10), 35.3 (C-4), 40.4 (C-5), 45.9 (C-6), 48.5 (C-2), 53.4 (C-3), 110.2 (C-9), 127.4 (C-4'), 129.1 (2C, C-3' and C-5'), ** 132.5 (2C, C-2' and C-6'),** 134.6 (C-1'), 146.9 (C-8) and 209.7 (C-1).
5-Isopropenyl-2-methyl-3-phenylsulfanyl-cyclohexanones 7a-c under thermodynamic conditions: A solution of thiophenol $(5.15 \mathrm{~mL}, 50 \mathrm{mmol})$ and $\mathrm{Et}_{3} \mathrm{~N}$ $(1.0 \mathrm{~mL}, 14 \mathrm{mmol})$ in $\mathrm{CHCl}_{3}(30 \mathrm{~mL})$, was treated dropwise with $(R)$-carvone $(1.56 \mathrm{~mL}, 10 \mathrm{mmol})$ and the resulting reaction mixture was stirred 3 days under reflux. Then the reaction was diluted with brine $(5 \times 10 \mathrm{~mL})$ and the products were extracted with EtOAc $(3 \times 10 \mathrm{~mL})$. The combined organic extracts were dried under $\mathrm{Na}_{2} \mathrm{SO}_{4}$, concentrated under reduced pressure, leaving an oily residue which was flash-chromatographed (hexane-EtOAc, slow gradient from 99.5:0.5 to 95:5), furnishing three relevant fractions.

(2S,3R,5S)-5-Isopropenyl-2-methyl-3-phenylsulfanylcyclohexanone $7 a$ : Yield $=105 \mathrm{mg}, 4 \%$. Melting point, specific rotation and spectral data in agreement with the compound previously accessed under kinetic conditions. ${ }^{21}$

(2S, 3S, 5S)-5-Isopropenyl-2-methyl-3-phenylsulfanylcyclohexanone $7 \boldsymbol{b}$ : Yield $=889 \mathrm{mg}, 34 \%$. White solid, mp 67-69 ${ }^{\circ} \mathrm{C}$ (hexane-AcOEt). $[\alpha]_{\mathrm{D}}{ }^{25}-95.0$ (c 0.96, $\left.\mathrm{CHCl}_{3}\right)$. Lit.: mp 68-69 ${ }^{\circ} \mathrm{C} .{ }^{20}[\alpha]_{\mathrm{D}}{ }^{25}-95\left(c 4, \mathrm{CHCl}_{3}\right)$. IR $\left(\mathrm{KBr}, v_{\max } / \mathrm{cm}^{-1}\right)$ : 3071, 2927, 2850, 1707, 1643, 1436, 1379, 1210, 902, 749 and 692. ${ }^{1} \mathrm{H}$ NMR: $\delta 1.33$ (d, 3H, $J 6.5$, $\mathrm{H}-7$ ), 1.69 (s, 3H, H-10), 1.74-1.84 (m, 1H, H-4 ${ }_{\text {ax }}$, 2.23-2.42 (m, 4H, H-2, H-4 $4_{\text {eq }}$ H-5 and H-6 ${ }_{\text {eq }}$ ), 2.46 (dd, 1H, J 2.3 and 9.2, H-6 $\left.6_{\mathrm{ax}}\right), 2.91$ (dt, $1 \mathrm{H}, J 3.7$ and 12.1, H-3), 4.69 (s, 1H, H-9) $) 4.75$ (s, 1H, H-9 ), 7.16-7.39 (m, 3H, ArH-3', ArH5' and ArH-4') and 7.40-7.54 (m, 2H, ArH-2' and ArH-6'). ${ }^{13}$ C NMR: $\delta$ 12.6 (C-7), 20.2 (C-10), 39.1 (C-4), 43.9 (C-5), 46.3 (C-6), 49.5 (C-2), 53.3 (C-3), 110.2 (C-9), 127.7 (ArC4'), 128.9 (2C, ArC-3' and ArC-5'), 133.1 (ArC-1'), 133.5 (2C, ArC-2' and ArC-6'), 146.3 (C-8) and 209.5 (C-1).

(2R,3S, 5S)-5-Isopropenyl-2-methyl-3-phenylsulfanylcyclohexanone $7 c$ : Oil. Yield $=419 \mathrm{mg}, 16 \%$. $[\alpha]_{\mathrm{D}}^{25}+37.9\left(c 1.57, \mathrm{CHCl}_{3}\right)$. IR (film, $\left.v_{\max } / \mathrm{cm}^{-1}\right): 2971$, 2934, 1712, 1644, 1584, 1480, 1439, 1377, 1280, 1216, 1089, 1025, 749 and 692. ${ }^{1} \mathrm{H}$ NMR: $\delta 1.29$ (d, 3H, $J$ 6.9, H-7), 1.65 (s, 3H, H-10), 1.95 (ddd, $1 \mathrm{H}, J$ 4.1, 7.5 and 14.2, $\mathrm{H}-4_{\mathrm{ax}}$ ), 2.20 (ddd, $1 \mathrm{H}, J 3.7,7.8$ and 14.2, $\mathrm{H}-4_{\mathrm{eq}}$ ), 2.39-2.50 (m, 1H, H-2), 2.43 (dd, 1H, J 6.1 and 14.2, H- $6_{\mathrm{ax}}$ ), 2.56 (dd, $1 \mathrm{H}, J 7.3$ and $14.2, \mathrm{H}-6_{\mathrm{eq}}$ ), 2.77-2.88 (m, 1H, H-5), 3.29 (dt, $1 \mathrm{H}, J 3.7$ and 7.5, H-3), 4.68 (bs, $1 \mathrm{H}, \mathrm{H}-9 \mathrm{~b}$ ), 4.82 (bs, 1H, H-9 ), 7.25-7.37 (m, 3H, Ar-3', ArH-4' and Ar-5') and 7.39-7.46 (m, 2H, Ar-2' and Ar-6'). ${ }^{13} \mathrm{C}$ NMR: $\delta 15.1$ (C-7), 21.4 (C-10), 32.4 (C-4), 39.9 (C-5), 43.2 (C-6), 49.1 (C-2), 49.9 (C-3), 111.5 (C-9), 127.6 (ArC-4'), 129.0 (2C, ArC-3' and ArC-5'), 133.1 (2C, ArC-2' and ArC-6'), 133.4 (ArC-1'), 146.2 (C-8) and 211.0 (C-1). 
(2S,3R,5S)-5-Isopropenyl-2-methyl-3-(naphthalen-2ylsulfanyl)-cyclohexanone 8: 2-Naphthalenethiol (303 mg, $1.9 \mathrm{mmol}$ ) was added to a stirred solution of $(R)$-carvone $(285 \mathrm{mg}, 1.9 \mathrm{mmol})$ and $\mathrm{Et}_{3} \mathrm{~N}(0.7 \mathrm{~mL}, 0.95 \mathrm{mmol})$ in anhydrous hexane $(10 \mathrm{~mL})$, cooled at $0{ }^{\circ} \mathrm{C}$. The resulting solution was stirred $8 \mathrm{~h}$ at $0{ }^{\circ} \mathrm{C}$ while a white precipitate was formed. The precipitate was separated from the solution, washed twice with hexane $(2 \times 5 \mathrm{~mL})$ and dried under reduced pressure, affording 8 (540 $\mathrm{mg}, 92 \%)$, as a white solid mp $113-116^{\circ} \mathrm{C}$ (hexane-EtOAc). $[\alpha]_{\mathrm{D}}^{25}-96.7\left(c 1.0, \mathrm{CHCl}_{3}\right)$. IR $\left(\mathrm{KBr}, v_{\max } / \mathrm{cm}^{-1}\right): 3054,2925,2844,1711,1443,1378$, 1208, 1141, 1015, 889, 858, 825 and 744. ${ }^{1}$ H NMR: $\delta 1.25$ (d, 3H, J 7.5, H-7), 1.64 (s, 3H, H-10), 1.92 (ddd, 1H, J 3.2, 4.9 and $\left.13.9, \mathrm{H}-4_{\mathrm{ax}}\right), 2.10$ (ddt, $1 \mathrm{H}, J 2.1,3.6$ and $13.9, \mathrm{H}-4_{\mathrm{eq}}$ ), 2.30 (ddd, $1 \mathrm{H}, J 1.2,12.6$ and 13.7, $\mathrm{H}-6_{\text {ax }}$ ), 2.56 (ddd, $1 \mathrm{H}, J$ 2.0, 4.3 and 13.6, $\mathrm{H}-6_{\mathrm{eq}}$ ), 2.92 (ddq, $1 \mathrm{H}, J$ 1.2, 4.8 and 7.5, $\mathrm{H}-2$ ), 3.08 (ttd, $J 4.1$ and 12.0, $\mathrm{H}-5$ ), 4.02 (dq, $1 \mathrm{H}, J 1.3$ and $7.5, \mathrm{H}-3), 4.71$ (d, 1H, $J 0.6, \mathrm{H}-9 \mathrm{~b}), 4.76(\mathrm{~d}, 1 \mathrm{H}, J 0.6, \mathrm{H}-9$ ), 7.45-7.50 (m, 3H, H-3', H-6' and H-7'), 7.70-7.80 (m, 3H, H-4', H-5' and H-8') and 7.88 (bs, $\left.1 \mathrm{H}, \mathrm{H}-1^{\prime}\right) .{ }^{13} \mathrm{C}$ NMR: $\delta$ 12.8 (C-7), 20.8 (C-10), 35.4 (C-4), 40.5 (C-5), 46.0 (C-6), 48.5 (C-2), 53.3 (C-3), 110.3 (C-9), 126.3 (C-6'), 126.7

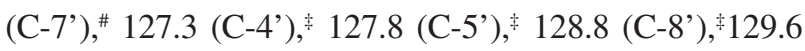
(C-3'), ${ }^{\prime} 131.2$ (C-1'), 131.9 (C-2'), * 132.4 (C-8a'), * 133.7 (C-4a'), ${ }^{*} 146.9(\mathrm{C}-8)$ and $209.8(\mathrm{C}-1)$.

(1S,2S,3R,5S)-5-Isopropenyl-2-methyl-3-(naphthalen2-ylsulfanyl)-cyclohexanol 10: A solution of 8 (140 mg, $0.45 \mathrm{mmol})$ in THF $(3 \mathrm{~mL})$, was cooled to $-78^{\circ} \mathrm{C}$ and treated dropwise with K-Selectride $(2.7 \mathrm{~mL}, 1.34 \mathrm{mmol})$. The reaction was stirred at $-78^{\circ} \mathrm{C}$ during $2 \mathrm{~h}$, when acetone $(0.1 \mathrm{~mL})$ was added to destroy the remaining reducing agent, and the solvent was removed under reduced pressure leaving an oily residue, which was chromatographed, furnishing 10 (93 mg, 66\%), as a yellow solid, $\mathrm{mp} 56-59^{\circ} \mathrm{C}$ (hexaneEtOAc). $[\alpha]_{\mathrm{D}}{ }^{25}-88.0\left(\mathrm{c} 0.75, \mathrm{CHCl}_{3}\right)$. IR $\left(\mathrm{KBr}, \nu_{\max } / \mathrm{cm}^{-1}\right)$ : 3462, 3052, 2927, 1643, 1624, 1587, 1500, 1448, 1375, 1193, 1133, 1052, 944, 888, 857, 814, 746 and 602. ${ }^{1} \mathrm{H}$ NMR: $\delta$ 1.29 (d, 3H, J 7.1, H-7), 1.51 (ddd, 1H, J3.0, 12.0 and 14.2, $\mathrm{H}-6_{\mathrm{ax}}$ ), 1.56 (ddd, $1 \mathrm{H}, J$ 3.0, 12.0 and 14.9, $\mathrm{H}-4_{\mathrm{ax}}$ ), 1.68 (s, $3 \mathrm{H}, \mathrm{H}-10), 1.98-2.11$ (m, 3H, H-2, H-4 eq and H- $6_{\text {eq }}$ ), 2.81 (tt, $1 \mathrm{H}, J 3.0,12.0$ and 12.0, H-5), 3.66 (dt, $1 \mathrm{H}, J 3.6$ and 3.8, $\mathrm{H}-3$ ), 3.95 (dt, 1H, J 3.0 and 3.1, H-1), 4.71 (bt, 1H, J 0.9, H-9), 4.72 (bt, 1H, J 0.9, H-9), 7.44-7.51 (m, 3H, H-3', H-6' and $\mathrm{H}^{-7}$ '), 7.73-7.81 (m, 3H, H-4', H-5' and H-8') and 7.88 (d, 1H, $J$ 1.7, H-1'). ${ }^{13} \mathrm{C}$ NMR: $\delta 16.2$ (C-7), 21.1 (C-10), 32.7 (C-5), 36.1 (C-4), 38.0 (C-6), 39.0 (C-2), 50.6 (C-3), 71.4 (C-1), 109.1 (C-8), 125.8 (C-6'), 126.3 (C-7'), 127.1 (C-4'), ${ }^{\ddagger} 127.5$ (C-5'), 128.3 (C-8'), 129.1 (C-3'), ${ }^{\#} 129.8$ (C-1'), 132.0 (C-2'), * 133.6 (C-8a'), * 133.8 (C-4a')* and 148.9 (C-8).
(1S,2S,3R, 5S)-5-Isopropenyl-2-methyl-3-phenylsulfanylcyclohexanol 9a: A solution of ketone 7a $(22 \mathrm{mg}$, $0.08 \mathrm{mmol})$ in THF $(5 \mathrm{~mL})$, was cooled to $-78{ }^{\circ} \mathrm{C}$ and treated with K-Selectride $(0.24 \mathrm{~mL}, 0.12 \mathrm{mmol})$. The mixture was stirred $2 \mathrm{~h}$ at $-78^{\circ} \mathrm{C}$, then acetone $(0.1 \mathrm{~mL})$ was added to destroy the remainder of the reducing agent and the solvent was removed under reduced pressure, leaving an oily residue, which was chromatographed, yielding $\mathbf{9 a}$ (13 mg, 58\%), as an oil. $[\alpha]_{\mathrm{D}}^{25}-28.6\left(c 1.42, \mathrm{CHCl}_{3}\right)$. IR (film, $v_{\max } / \mathrm{cm}^{-1}$ ): 3421, 2927, 2872, 2360, 1645, 1436, 1024, 975, 949 and 889. 'H NMR: $\delta 1.25$ (ddd, 1H, J 10.7, 12.0 and $12.2, \mathrm{H}_{-\mathrm{ax}}$ ), 1.26 (d, 3H, J 6.7, H-7), 1.49 (ddd, $1 \mathrm{H}, J$ 3.4, 12.2 and 13.4, $\mathrm{H}-4{ }_{\mathrm{ax}}$ ), 1.63 (bs, $\left.1 \mathrm{H}, \mathrm{OH}\right), 1.69$ (s, 3H, H-10), 1.73-1.83 (m, 1H, H-2), 1.93 (dq, 1H, J 4.1 and 13.4, H-4 ${ }_{\text {eq }}$ ), 2.05-2.13 (m, 1H, H- ${ }_{\text {eq }}$ ), 2.67 (tt, $1 \mathrm{H}, J$ 3.1 and 12.2, H-5), 3.57 (dd, $1 \mathrm{H}, J 3.4$ and 7.0, H-3), 3.63 (dt, $1 \mathrm{H}, J 4.5$ and 10.7, H-1), 4.71 (s, 2H, H-9), 7.18-7.32 (m, 3H, H-3', H-4' and H-5') and 7.38-7.45 (m, 2H, H-2' and H-6'). ${ }^{13} \mathrm{C}$ NMR: $\delta 16.3(\mathrm{C}-7), 21.1(\mathrm{C}-10), 36.8(\mathrm{C}-4)$, 38.3 (C-5), 40.6 (C-6), 43.7 (C-2), 53.8 (C-3), 71.9 (C-1), 109.1 (C-9), 126.8 (C-4'), 129.0 (2C, C-3' and C-5'), 131. 9 (2C, C-2' and C-6'), 136.3 (C-1') and 148.6 (C-8).

(1S, 2S,3R,5S)-5-Isopropenyl-2-methyl-3-phenylsulfanylcyclohexanol $\mathbf{9 b}$ : K-Selectride $(0.214 \mathrm{~mL}$, $0.107 \mathrm{mmol}$ ) was added dropwise to a solution of ketone 7b (18.6 mg, $0.071 \mathrm{mmol})$ in anhydrous THF (2 mL), kept at $-78^{\circ} \mathrm{C}$, and the reaction was further stirred $24 \mathrm{~h}$ at this temperature. Then, the solvent was removed under reduced pressure and the residue was subjected to chromatography, furnishing $9 \mathbf{b}$ (13 mg, 66\%), as an oil. $[\alpha]_{\mathrm{D}}{ }^{25}+118.7$ ( $c 0.94$, $\mathrm{CHCl}_{3}$ ). IR (film, $v_{\text {max }} / \mathrm{cm}^{-1}$ ): 3447, 2928, 2359, 1643, 1582, 1437, 1180, 949, 889, 743 and 691. ${ }^{1} \mathrm{H}$ NMR: $\delta 1.33(\mathrm{~d}, 3 \mathrm{H}$, $J$ 6.5, H-7), 1.29-1.49 (m, 2H, H-4 ax and $\left.\mathrm{H}-6_{\mathrm{ax}}\right), 1.50-1.61$ (m, 1H, H-2), 1.67 (d, 3H, $J$ 1.1, H-10), 1.91 (ddt, 1H, $J$ 2.5, 3.3 and 12.6, $\mathrm{H}-6_{\mathrm{eq}}$ ), 2.12 (ddt, $1 \mathrm{H}, J 2.5,3.3$ and 13.0, $\mathrm{H}-4_{\text {eq }}$ ), 2.43 (tt, $1 \mathrm{H} J 3.3$ and 12.7, H-5), 3.19 (dt, 1H J 3.3 and 11.8, H-3), 4.01 (d, 1H, $J$ 2.5, H-1), 4.66 (dd, 1H, $J$ 0.9 and 1.8, H- 9 ), 4.68 (s, 1H, H-9 $)$, 7.18-7.34 (m, 3H, ArH-3', ArH-4' and ArH-5') and 7.37-7.47 (m, 2H, ArH2' and ArH-6'). ${ }^{13} \mathrm{C}$ NMR: $\delta 16.9$ (C-7), 20.7 (C-10), 38.2 (C-6), 38.3 (C-5), 39.7 (C-4), 40.9 (C-2), 48.4 (C-3), 71.8 (C-1), 109.0 (C-9), 126.7 (ArC-4'), 128.7 (2C, ArC-3' and ArC-5'), 132.2 (2C, ArC-2' and ArC-6'), 134.7 (ArC-1') and $148.8(\mathrm{C}-8)$.

(2S,3R,5S)-3-Benzenesulfonyl-5-isopropenyl-2methylcyclohexanone 11: A solution of $\left(\mathrm{NH}_{4}\right)_{6} \mathrm{Mo}_{7} \mathrm{O}_{24} \cdot 4 \mathrm{H}_{2} \mathrm{O}$ (30 mg, $0.0237 \mathrm{mmol})$ and $30 \% \mathrm{H}_{2} \mathrm{O}_{2}(0.140 \mathrm{~mL}$, $0.138 \mathrm{mmol}$ ) was cooled to $0{ }^{\circ} \mathrm{C}$ and added through a cannula to ketone $7 \mathbf{b}$ (55 mg, $0.212 \mathrm{mmol})$ dissolved in ethanol 
$(2 \mathrm{~mL})$. The reaction mixture was stirred $3 \mathrm{~h}$ at $0{ }^{\circ} \mathrm{C}$, brine was added, and the reaction products were extracted with $\mathrm{Et}_{2} \mathrm{O}(5 \times 10 \mathrm{~mL})$. The combined organic extracts were dried $\left(\mathrm{Na}_{2} \mathrm{SO}_{4}\right)$ concentrated under reduced pressure and the residue was chromatographed, affording sulfone 11 (32 $\mathrm{mg}, 52 \%$ ), as a white solid $\mathrm{mp} 73-74{ }^{\circ} \mathrm{C}$ (hexane-EtOAc). $[\alpha]_{\mathrm{D}}^{25}-27.0\left(\mathrm{c} 0.91, \mathrm{CHCl}_{3}\right)$. IR $\left(\mathrm{KBr}, v_{\max } / \mathrm{cm}^{-1}\right): 2924$, 1713, 1447, 1305, 1144, 1083, 898, 747 and 690. ${ }^{1} \mathrm{H}$ NMR: $\delta 1.36$ (d, 3H, J 6.6, H-7), 1.66 (s, 3H, H-10), 1.71-1.88 (m, $1 \mathrm{H}, \mathrm{H}-4_{\mathrm{ax}}$ ), 2.04 (ddd, $1 \mathrm{H}, J 2.8,3.9$ and 11.7, $\mathrm{H}-4_{\mathrm{eq}}$ ), 2.182.32 (m, 1H, H-5), 2.20-2.34 (m, 1H, H-6 ${ }_{\text {eq }}$ ), 2.42-2.58 (m, $\left.1 \mathrm{H}, \mathrm{H}-6_{\mathrm{ax}}\right), 2.75$ (dq, $1 \mathrm{H} \mathrm{J} 6.6$ and 12.8, H-2), 3.14 (ddd, $1 \mathrm{H}$, $J$ 3.9, 11.3 and 12.8, H-3), 4.68 (s, 1H, H-9 $), 4.78$ (s, 1H, H-9 $)$, 7.55-7.73 (m, 3H, ArH-3', ArH-4' and ArH-5') and 7.87-7.94 (m, 2H, ArH-2' and ArH-6'). ${ }^{13} \mathrm{C}$ NMR: $\delta 13.3$ (C-7), 20.0 (C-10), 31.7 (C-4), 42.3 (C-5), 44.1 (C-2), 45.5 (C-6), 67.8 (C-3), 111.0 (C-9), 128.6 (2C, ArC-2 and ArC-6), 129.3 (2C, ArC-3 and ArC-5), 134.0 (ArC-4), 137.9 (ArC1), 145.5 (C-8) and 207.7 (C-1). Increasing solvent polarity afforded sulfoxide 12 (14 mg, 25\%).

(2S,3R,5S)-3-Benzenesulfinyl-5-isopropenyl-2methylcyclohexanone 12: A solution of $\left(\mathrm{NH}_{4}\right)_{6} \mathrm{Mo}_{7} \mathrm{O}_{24} \cdot 4 \mathrm{H}_{2} \mathrm{O}$ (27 mg, $0.0211 \mathrm{mmol})$ and $30 \% \mathrm{H}_{2} \mathrm{O}_{2}(0.05 \mathrm{~mL}, 0.062 \mathrm{mmol})$ was cooled to $0^{\circ} \mathrm{C}$ and added through a cannula to ketone $7 \mathbf{b}$ (49 mg, $0.19 \mathrm{mmol}$ ) dissolved in ethanol $(2 \mathrm{~mL})$. The reaction mixture was stirred $3 \mathrm{~h}$ at $0{ }^{\circ} \mathrm{C}$, brine was added, and the reaction products were extracted with $\mathrm{Et}_{2} \mathrm{O}(5 \times 10 \mathrm{~mL})$. The combined organic extracts were dried $\left(\mathrm{Na}_{2} \mathrm{SO}_{4}\right)$ concentrated under reduced pressure and the residue was chromatographed, affording sulfone $\mathbf{1 1}(2.4 \mathrm{mg}, 5 \%)$. Increasing solvent polarity afforded sulfoxide $12(23 \mathrm{mg}, 47 \%)$, as a white solid mp $103-105{ }^{\circ} \mathrm{C}$ (hexane-EtOAc). $[\alpha]_{\mathrm{D}}^{25}+93.3\left(c 0.95, \mathrm{CHCl}_{3}\right)$. IR $\left(\mathrm{KBr}, v_{\max } / \mathrm{cm}^{-1}\right): 2932,1713,1442,1215,1084,1039$, 902, 746 and 700. ${ }^{1} \mathrm{H}$ NMR: $\delta 1.34$ (ddd, $1 \mathrm{H}, J 3.0,3.9$ and 13.0, H-4 ${ }_{\mathrm{eq}}$ ) 1.47 (d, 3H, J 6.5, H-7), 1.61 (s, 3H, H-10), 2.05 (ddd, $1 \mathrm{H} J 12.2,12.5$ and 13.0, $\mathrm{H}-4_{\mathrm{ax}}$ ), 2.21 (tt, $1 \mathrm{H}, J$ 3.0 and 12.2, H-5), 2.33 (dd, $1 \mathrm{H}, J 12.2$ and 12.6, $\mathrm{H}-6_{\mathrm{ax}}$ ), $2.42(\mathrm{dt}, 1 \mathrm{H}, J 3.9$ and $12.5, \mathrm{H}-3), 2.45(\mathrm{dd}, 1 \mathrm{H}, J 3.0$ and $12.6, \mathrm{H}_{-} \mathrm{e}_{\mathrm{eq}}$ ), 2.88 (dq, $1 \mathrm{H}, J 6.5$ and $\left.12.5, \mathrm{H}-2\right), 4.66$ (s, $1 \mathrm{H}$, $\mathrm{H}-9$ ) ) 4.71 (s, 1H, H-9) $)$ 7.47-7.56 (m, 5H, ArH). ${ }^{13} \mathrm{C} \mathrm{NMR:}$ $\delta 12.1$ (C-7), 19.8 (C-10), 24.2 (C-4), 43.0 (C-5), 44.4 (C-2), 45.8 (C-6), 68.2 (C-3), 110.8 (C-9), 124.0 (2C, ArC-2' and ArC-6'), 129.1 (2C, ArC-3' and ArC-5'), 130.7 (ArC-4'), 140.8 (ArC-1'), 146.0 (C-8) and 209.1 (C-1).

(1S,2S,3S, 5S)-3-Benzenesulfonyl-5-isopropenyl-2methylcyclohexanol 13: A solution of alcohol $9 \mathbf{b}(137 \mathrm{mg}$, $0.521 \mathrm{mmol})$ in ethanol $(10 \mathrm{~mL})$ was cooled to $0{ }^{\circ} \mathrm{C}$ and added dropwise to a solution of $\left(\mathrm{NH}_{4}\right)_{6} \mathrm{Mo}_{7} \mathrm{O}_{24} \cdot 4 \mathrm{H}_{2} \mathrm{O}$ (74 mg, $0.059 \mathrm{mmol})$ in $30 \% \mathrm{H}_{2} \mathrm{O}_{2}(0.32 \mathrm{~mL}, 2.85 \mathrm{mmol})$ cooled in an ice bath, and the resulting mixture was stirred $24 \mathrm{~h}$ at $0^{\circ} \mathrm{C}$. Then, brine $(10 \mathrm{~mL})$ was added and the products were extracted with $\mathrm{Et}_{2} \mathrm{O}(5 \times 10 \mathrm{~mL})$. The combined extracts were washed with brine $(5 \mathrm{~mL})$, dried over $\mathrm{Na}_{2} \mathrm{SO}_{4}$ and concentrated under reduced pressure, leaving a residue which was chromatographed, furnishing alcohol 13 (92 mg, $60 \%$ ) as a white solid mp $116-118{ }^{\circ} \mathrm{C}$ (hexane-EtOAc). $[\alpha]_{\mathrm{D}}^{25}+22.3\left(\mathrm{c} 0.47, \mathrm{CHCl}_{3}\right)$. IR $\left(\mathrm{KBr}, \mathrm{v}_{\max } / \mathrm{cm}^{-1}\right): 3504$, 2938, 1437, 1282, 1141, 1086, 752, 719 and $690 \mathrm{~cm}^{-1}$. ${ }^{1} \mathrm{H}$ RMN: $\delta 1.29$ (ddd, $1 \mathrm{H}, J$ 12.5, 12.6 and 12.6, $\mathrm{H}-4_{\mathrm{ax}}$ ), 1.36 (dt, $1 \mathrm{H}, J 2.7$ and 12.0, H-6 $6_{\mathrm{ax}}$ ), 1.37 (d, 3H, $J$ 6.8, $\mathrm{H}-7$ ), 1.62 (s, 3H, H-10), 1.75 (ddd, 1H, J 2.7, 3.3 and 12.6, H-4 $\left.{ }_{\text {eq }}\right), 1.83-1.90$ (m, 1H, H-6 $\left.{ }_{\text {eq }}\right), 1.90-1.97$ (m, $1 \mathrm{H}$, $\mathrm{H}-2$ ), 2.39 (tt, $1 \mathrm{H}, J 2.7$ and 12.5, H-5), 3.31 (ddd, $1 \mathrm{H}, J$ 3.3, 11.2 and 12.6, H-3), 3.93-3.99 (m, 1H, H-1), 4.62 (s, 1H, H-9 ${ }_{\mathrm{b}}$ ), 4.69 (s, 1H, H-9 $), 7.51-7.60$ (m, 2H, ArH-3' and ArH-5'), 7.60-7.68 (m, 1H, ArH-4') and 7.83-7.91 (m, 2H, ArH-2' and ArH-6'). ${ }^{13} \mathrm{C}$ NMR: $\delta 17.5$ (C-7), 20.5 (C-10), 32.1 (C-4), 36.5 (C-5),**36.7 (C-2),**37.6 (C-6), 63.7 (C-3), 72.5 (C-1), 109.6 (C-9), 128.4 (2C, ArC-2' and ArC-6'), 128.9 (2C, ArC-3' and ArC-5'), 133.4 (ArC-4'), 138.5 (ArC-1') and 147.8 (C-8).

(1S, 2S,3S, 5S)-3-Benzenesulfinyl-5-isopropenyl-2methylcyclohexanol 14: A solution of sulfoxide $12(71 \mathrm{mg}$, $0.257 \mathrm{mmol})$ in THF $(5 \mathrm{~mL})$ was cooled to $-78^{\circ} \mathrm{C}$, treated dropwise with K-Selectride $(0.32 \mathrm{~mL}, 0.385 \mathrm{mmol})$ and the resulting mixture was stirred 2 days at $-78^{\circ} \mathrm{C}$. Then, the solvent was removed under reduced pressure and the remaining oil was chromatographed, furnishing alcohol 14 (32 mg, 44\%) as a white solid, $\mathrm{mp} 125-127^{\circ} \mathrm{C}$ (hexaneEtOAc). $[\alpha]_{\mathrm{D}}{ }^{25}+32.7\left(\mathrm{c} 0.55, \mathrm{CHCl}_{3}\right)$. IR $\left(\mathrm{KBr}, v_{\max } / \mathrm{cm}^{-1}\right)$ : 3404, 2925, 1643, 1443, 1084, 1014, 885, 740 and 668. ${ }^{1} \mathrm{H}$ NMR: $\delta 1.15$ (ddd, $1 \mathrm{H}, J 3.5,3.7$ and 12.6, H-4 ${ }_{\text {eq }}$ ) 1.43 (ddd, $1 \mathrm{H}, J$ 2.4, 12.6 and $\left.13.4 \mathrm{H}-6_{\mathrm{ax}}\right), 1.44(\mathrm{~d}, 3 \mathrm{H}, J$ 6.8, $\mathrm{H}-7$ ), 1.58 (s, 3H, H-10), 1.60 (ddd, $1 \mathrm{H}, J$ 12.0, 12.6 and $12.6, \mathrm{H}-4_{\mathrm{ax}}$ ), 1.85 (ddd, $1 \mathrm{H}, J 2.2,3.5$ and 13.4, $\mathrm{H}-6_{\mathrm{eq}}$ ), 2.02 (ddq, $1 \mathrm{H}, J$ 2.2, 6.8 and 12.0, H-2), 2.34 (tt, $1 \mathrm{H}, J 3.5$ and 12.6, H-5), 2.58 (dt, 1H, J 3.7 and 12.0, H-3), 4.08 (ddd, $1 \mathrm{H}, J 2.2,2.2$ and 2.4, H-1), 4.61 (s, $1 \mathrm{H}, \mathrm{H}-9 \mathrm{~b}$ ), 4.63 (s, 1H, $\mathrm{H}-9$ ) and 7.41-7.50 (m, 5H, ArH). ${ }^{13} \mathrm{C}$ NMR: $\delta 16.3$ (C-7), 20.3 (C-10), 24.2 (C-4), 36.0 (C-5), 36.8 (C-2), 38.0 (C-6), 63.7 (C-3), 71.6 (C-1), 109.5 (C-9), 124.2 (2C, ArC-2' and ArC-6'), 128.8 (2C, ArC-3' and ArC-5'), 130.2 (ArC-4'), 141.2 (ArC-1') and 148.5 (C-8).

(1R,5R)-5-Isopropenyl-2-methyl-1-phenylcyclohex-2enol 15a: A suspension of Mg turnings ( $35 \mathrm{mg}, 1.46 \mathrm{mmol}$ ) in anhydrous $\mathrm{Et}_{2} \mathrm{O}(8 \mathrm{~mL})$ was submitted to reflux and treated dropwise with the bromobenzene $(0.15 \mathrm{~mL}$, $1.4 \mathrm{mmol}$ ) during $30 \mathrm{~min}$, and the resulting mixture was 
further heated to reflux during $1 \mathrm{~h}$. The Grignard reagent was cooled to $-20{ }^{\circ} \mathrm{C}$ and treated with $(R)$-carvone $(0.10 \mathrm{~mL}, 0.67 \mathrm{mmol})$ at room temperature. After 30 $\mathrm{min}$, the solvent was removed under reduced pressure and the residue was chromatographed, yielding alcohol 15a (114.7 $\mathrm{mg}, 75 \%)$ as an oil. $[\alpha]_{\mathrm{D}}{ }^{25}-122.4\left(c 1.19, \mathrm{CHCl}_{3}\right)$. IR (film, $v_{\max } / \mathrm{cm}^{-1}$ ): 3448, 1646, 1448, 1029, 934, 889, 768 and 703. ${ }^{1} \mathrm{H}$ NMR: $\delta 1.62$ (s, 3H, H-10), 1.65 (s, 3H, H-7), 1.93-2.19 (m, 4H, H- ${ }_{\text {ax }}$, H-5, H-6 $6_{\text {ax }}$ and H- $6_{\text {eq }}$ ), 2.20-2.31 (m, 1H, H-4 $4_{\text {eq }}$ ) 4.62 (s, 1H, H-9 $), 4.65$ (s, 1H, H-9 $), 5.79$ (m, 1H, H-3), 7.22-7.28 (m, 1H, ArH-4'), 7.30-7.37 (m, 2H, ArH-2' and ArH-6') and 7.44-7.49 (m, 2H, ArH-3' and ArH-5'). ${ }^{13} \mathrm{C}_{\mathrm{NMR}} \delta 17.8$ (C-7), 20.6 (C-10), 31.1 (C-4), 37.8 (C-5), 45.1 (C-6), 77.2 (C-1), 108.8 (C-9), 125.8 (ArC-4'), 126.2 (2C, ArC-2' and ArC-6'), 126.9 (C-3), 127.9 (2C, ArC-3' and ArC-5'), 135.8 (C-2), 145.6 (ArC-1') and 148.6 (C-8).

(1R,5R)-5-Isopropenyl-2-methyl-1-p-tolylcyclohex2-enol 15b: A suspension of $\mathrm{Mg}$ turnings $(212 \mathrm{mg}$, $8.71 \mathrm{mmol})$ in anhydrous THF $(8 \mathrm{~mL})$ was heated to $60^{\circ} \mathrm{C}$ and treated dropwise with a solution of bromotoluene $(1.37 \mathrm{~g}, 8.06 \mathrm{mmol})$ in THF $(2 \mathrm{~mL})$ during $30 \mathrm{~min}$ and the resulting mixture was further refluxed during $1 \mathrm{~h}$. The Grignard reagent was cooled to $-20{ }^{\circ} \mathrm{C}$ and treated with $(R)$-carvone $(1.0 \mathrm{~mL}, 6.7 \mathrm{mmol})$ at room temperature. After $1 \mathrm{~h}$, the solvent was removed under reduced pressure and the residue was chromatographed, yielding alcohol $\mathbf{1 5 b}$ (877 $\mathrm{mg}, 54 \%)$ as an oil. $[\alpha]_{\mathrm{D}}^{25}-154.2\left(c 2.50, \mathrm{CHCl}_{3}\right)$. IR (film, $v_{\text {max }} / \mathrm{cm}^{-1}$ ): 3420, 2918, 1645, 1508, 1447, 1375, 1022, 934, 899 and 820. ${ }^{1} \mathrm{H}$ NMR: $\delta 1.62$ (s, 3H, H-7), 1.64 (s, 3H, H-10), 1.87-2.17 (m, 4H, H-4 ${ }_{\mathrm{ax}}, \mathrm{H}-5, \mathrm{H}-6_{\mathrm{ax}}$ and $\left.\mathrm{H}-6_{\mathrm{eq}}\right), 2.29$ (ddd, $1 \mathrm{H}, J 1.6,3.1$ and $\left.16.5, \mathrm{H}-4_{\mathrm{eq}}\right), 2.33$ (s, 3H, ArMe), 4.61 (s, 1H, H-9 ) 4.64 (s, 1H, H-9 $), 5.75$ (ddq, 1H, $J$ 1.3, 2.8 and 3.7, H-3), 7.12 (dd, 2H, $J 1.9$ and 8.3, ArH-3' and ArH-5') and 7.34 (dt, 2H, $J 1.9$ and 8.3, ArH-2' and ArH-6'). ${ }^{13} \mathrm{C}$ NMR: $\delta 17.8$ (C-10), 20.4 (C-7), 20.7 ( $\mathrm{PhMe}$ ), 31.0 (C-4), 37.7 (C-5), 45.0 (C-6), 76.8 (C-1), 108.6 (C-9), 125.3 (C-3), 126.0 (2C, ArC-2' and ArC-6'), 128.4 (2C, ArC-3' and ArC-5'), 136.0 (ArC-4'), 136.2 (C2), 142.6 (ArC-1') and 148.4 (C-8).

(1R,5R)-5-Isopropenyl-2-methyl-1-(4-methoxyphenyl)cyclohex-2-enol 15c: A suspension of Mg turnings (35 mg, $1.46 \mathrm{mmol})$ in anhydrous THF $(5 \mathrm{~mL})$ was heated to $60^{\circ} \mathrm{C}$ and treated dropwise with a solution of bromoanisole (262 mg, $1.4 \mathrm{mmol})$ in THF ( $2 \mathrm{~mL}$ ) during $30 \mathrm{~min}$, and the resulting mixture was further refluxed during $1 \mathrm{~h}$. The Grignard reagent was cooled to $-20{ }^{\circ} \mathrm{C}$ and treated with $(R)$-carvone $(0.1 \mathrm{~mL}, 0.68 \mathrm{mmol})$ at room temperature. After $1 \mathrm{~h}$, the solvent was removed under reduced pressure and the residue was chromatographed, yielding alcohol 15c (102 mg, 59\%), as an oil. $[\alpha]_{\mathrm{D}}^{25}-153.3\left(c 4.88, \mathrm{CHCl}_{3}\right)$. IR (film, $\left.v_{\max } / \mathrm{cm}^{-1}\right)$ : 3431, 2916, 1608, 1508, 1248, 1175, 1036 and $833 .{ }^{1} \mathrm{H}$ NMR: $\delta 1.64$ (s, H-10), 1.68 (s, 3H, H-7), 1.92-2.18 (m, 3H, H-4 $4_{\text {ax }}, \mathrm{H}-5$ and H-6 ${ }_{\mathrm{eq}}$ ), 1.95 (t, $1 \mathrm{H}, \mathrm{J}$ 13.0, H- $\left.{ }_{\mathrm{ax}}\right), 2.19-2.31$ (m, 1H, H-4 $\left.{ }_{\mathrm{eq}}\right), 3.81$ (s, 3H, OMe), 4.64 (s, 1H, H-9 $), 4.67$ (s, 1H, H-9) $) 5.78$ (dd, 1H, $J 1.5$ and 4.8, H-3), 6.89 (d, 2H, J 8.8, ArH-3' and ArH-5') and 7.41 (d, 2H, J 8.8, ArH-2' and ArH-6'). ${ }^{13} \mathrm{C}$ NMR: $\delta 17.8$ (C-7), 20.5 (C-10), 31.1 (C-4), 37.8 (C-5), 45.2 (C-6), 54.9 (OMe), 76.7 (C-1), 108.7 (C-9), 113.1 (2C, ArC-3' and ArC-5'), 125.5 (C-3), 127.3 (2C, ArC-2' and ArC-6'), 136.0 (ArC1'), 137.7 (C-2), 148.5 (C-8) and 158.3 (ArC-4').

(5S)-5-Isopropenyl-2-methyl-3-phenylcyclohex-2enone 16a: $18 \%$ PCC on $\mathrm{Al}_{2} \mathrm{O}_{3}(9.34 \mathrm{~g}, 7.8 \mathrm{mmol})$ was added portionwise to a solution of alcohol $15 \mathbf{a}(741 \mathrm{mg}$, $3.25 \mathrm{mmol})$ in anhydrous $\mathrm{CH}_{2} \mathrm{Cl}_{2}(30 \mathrm{~mL})$, and the resulting suspension was stirred 3 days at room temperature. The solids were separated by filtration through Celite and the filter was washed with $\mathrm{CH}_{2} \mathrm{Cl}_{2}(3 \times 15 \mathrm{~mL})$. The filtrates were concentrated under reduced pressure and the residue was chromatographed, furnishing ketone 16a (599 mg, $82 \%$ ), as an oil. $[\alpha]_{\mathrm{D}}^{25}+152.6\left(c 0.85, \mathrm{CHCl}_{3}\right.$ ). IR (film, $\left.v_{\max } / \mathrm{cm}^{-1}\right): 2923,1668,1442,1108,893,765$ and 701. ${ }^{1} \mathrm{H}$ NMR: $\delta 1.73$ (s, 3H, H-7), 1.77 (s, 3H, H-10), 2.45 (dd, $1 \mathrm{H}, J 13.0$ and $\left.16.2, \mathrm{H}-4_{\mathrm{ax}}\right), 2.56-2.76\left(\mathrm{~m}, 3 \mathrm{H}, \mathrm{H}-4_{\mathrm{eq}}\right.$, $\mathrm{H}-6_{\mathrm{ax}}$ and $\mathrm{H}-6_{\mathrm{eq}}$ ), 2.82 (ddd, $1 \mathrm{H} \mathrm{J} 4.2,9.2$ and 17.7, H-5), 4.80 (s, 1H, H-9 $), 4.83$ (s, 1H, H-9 $\left.{ }_{\mathrm{a}}\right), 7.18-7.23$ (m, 2H, ArH-2' and ArH-6') and 7.28-7.43 (m, 3H, ArH-3', ArH4' and ArH-5'). RMN de ${ }^{13} \mathrm{C}: \delta 12.6$ (C-7), 20.4 (C-10), 37.9 (C-4), 41.6 (C-5), 42.5 (C-6), 110.5 (C-9), 127.0 (2C, ArC-2' and ArC-6'), 127.8 (ArC-4'), 128.3 (2C, ArC-3' and ArC-5'), 131.4 (C-2), 141.1 (ArC-1'), 146.4 (C-8), 155.4 (C-3) and $199.7(\mathrm{C}=\mathrm{O})$.

(5S)-5-Isopropenyl-2-methyl-3-p-tolylcyclohex-2enone 16b: $18 \%$ PCC on $\mathrm{Al}_{2} \mathrm{O}_{3}(5.17 \mathrm{~g}, 4.32 \mathrm{mmol})$ was added portionwise to a solution of alcohol $\mathbf{1 5 b}(435 \mathrm{mg}$, $1.80 \mathrm{mmol})$ in anhydrous $\mathrm{CH}_{2} \mathrm{Cl}_{2}(15 \mathrm{~mL})$, and the resulting suspension was stirred 3 days at room temperature. The solids were separated by filtration through Celite and the filter was washed with $\mathrm{CH}_{2} \mathrm{Cl}_{2}(3 \times 10 \mathrm{~mL})$. The filtrates were concentrated under reduced pressure and the residue was chromatoraphed, furnishing ketone 16b $(373 \mathrm{mg}$, $86 \%$ ), as an oil. $[\alpha]_{\mathrm{D}}^{25}+134.2\left(c 0.85, \mathrm{CHCl}_{3}\right)$. IR (film, $\left.v_{\max } / \mathrm{cm}^{-1}\right): 2920,1666,1510,1437,1377,1342,1107,893$ and $816 \mathrm{~cm}^{-1} .{ }^{1} \mathrm{H}$ NMR: $\delta 1.74$ (s, 3H, H-7), 1.77 (s, 3H, H-10), 2.38 (s, 3H, ArMe), 2.44 (dd, 1H, $J 12.9$ and 16.1, $\mathrm{H}-4_{\mathrm{ax}}$ ), 2.54-2.75 (m, 3H, H- ${ }_{\mathrm{eq}}, \mathrm{H}-6_{\mathrm{ax}}$ and $\mathrm{H}-6_{\mathrm{eq}}$ ), 2.81 (ddd, $1 \mathrm{H}, J$ 4.4, 9.8 and 13.7, H-5), 4.79 (s, 1H, H-9 b $^{2}, 4.83$ (s, 
1H, H-9 $\left.{ }_{\mathrm{a}}\right), 7.12$ (d, 2H, J 8.0, ArH-2' and ArH-6') and 7.21 (d, $2 \mathrm{H}, J$ 8.0, ArH-3' and ArH-5'). ${ }^{13} \mathrm{C}$ NMR: $\delta 12.7$ (C7), 20.4 (C-10), 21.1 (ArMe), 38.0 (C-4), 41.6 (C-5), 42.5 (C-6), 110.4 (C-9), 127.1 (2C, ArC-2' and ArC-6'), 128.9 (2C, ArC-3' and ArC-5'), 131.2 (C-2), 137.8 (ArC-1'), 138.1 (ArC-4'), 146.6 (C-8), 155.6 (C-3) and $199.8(\mathrm{C}=\mathrm{O})$.

(5S)-5-Isopropenyl-2-methyl-3-(4-methoxyphenyl)cyclohex-2-enone 16c: $18 \% \mathrm{PCC}$ on $\mathrm{Al}_{2} \mathrm{O}_{3}(1.09 \mathrm{~g}$, $0.91 \mathrm{mmol}$ ) was added portionwise to a solution of alcohol 15 c $(98 \mathrm{mg}, 0.38 \mathrm{mmol})$ in anhydrous $\mathrm{CH}_{2} \mathrm{Cl}_{2}(15 \mathrm{~mL})$, and the resulting suspension was stirred 1 day at room temperature. The solids were separated by filtration through Celite and the filter was washed with $\mathrm{CH}_{2} \mathrm{Cl}_{2}(3 \times 10 \mathrm{~mL})$. The filtrates were concentrated under reduced pressure and the residue was chromatoraphed, furnishing ketone 16c (69 $\mathrm{mg}, 71 \%$ ), as an oil. $[\alpha]_{\mathrm{D}}^{25}+190.6\left(c 1.13, \mathrm{CHCl}_{3}\right.$ ). IR (film, $v_{\max } / \mathrm{cm}^{-1}$ ): 2953, 1665, 1607, 1510, 1441, 1287, 1250, 1179, 1107, 1034 and 831. ${ }^{1} \mathrm{H}$ NMR: $\delta 1.76$ (s, 3H, $\mathrm{H}-7),{ }^{*} 1.78(\mathrm{~s}, 3 \mathrm{H}, \mathrm{H}-10),{ }^{*} 2.43$ (dd, $1 \mathrm{H}, J 13.0$ and 15.9. $\left.\mathrm{H}-6_{\mathrm{ax}}\right), 2.56-2.81\left(\mathrm{~m}, 3 \mathrm{H}, \mathrm{H}-4_{\mathrm{ax}}, \mathrm{H}-4_{\mathrm{eq}}\right.$ and $\left.\mathrm{H}-6_{\mathrm{eq}}\right), 2.76-2.90$ (m, 1H, H-5), 3.84 (s, 3H, OMe), 4.80 (s, 1H, H-9 ${ }_{\mathrm{b}}$ ), 4.83 (s, 1H, H-9) 6.93 (d, 2H, J 8.9, ArH-3' and ArH-5') and 7.18 (d, $2 \mathrm{H}, J$ 8.9, ArH-2' and ArH-6'). ${ }^{13} \mathrm{C}$ NMR: $\delta 13.0$ (C-7), 20.6 (C-10), 38.1 (C-4), 41.6 (C-5), 42.6 (C-6), 55.3 (OMe), 110.5 (C-9), 113.7 (2C, ArC-3' and ArC-5'), 128.8 (2C, ArC-2' and ArC-6'), 131.2 (C-2), 133.3 (ArC-1'), 146.7 (C-8), 155.3 (C-3), 159.4 (ArC-4') and 199.9 (C-

(1S,5S)-5-Isopropenyl-2-methyl-3-phenylcyclohex-2enol 17a: A solution of ketone 16a (575 mg, $2.54 \mathrm{mmol})$ in THF $(5 \mathrm{~mL})$ was transferred to a suspension of $\mathrm{NaBH}_{4}$ (97 mg, $2.54 \mathrm{mmol})$ in a 5:3 THF-MeOH $(8 \mathrm{~mL})$ mixture cooled at $0{ }^{\circ} \mathrm{C}$. After $1 \mathrm{~h}$, the solvent was removed under reduced pressure and the residue was chromatographed, affording alcohol 17a (504 mg, 88\%), as an oil, $[\alpha]_{D}{ }^{25}$ +81.0 (c 0.57, $\mathrm{CHCl}_{3}$ ). IR (film, $v_{\max } / \mathrm{cm}^{-1}$ ): 3355, 2921, 1442, 1043, 890, 765 and 700. ${ }^{1} \mathrm{H}$ NMR: $\delta$ 1.58-1.73 (m, $1 \mathrm{H}, \mathrm{H}-6_{\mathrm{ax}}$ ), 1.66 (s, 3H, H-7), 1.77 (s, 3H, H-10), 2.19$2.49\left(\mathrm{~m}, 4 \mathrm{H}, \mathrm{H}-4_{\mathrm{ax}}, \mathrm{H}-4_{\mathrm{eq}}, \mathrm{H}-5\right.$ and $\left.\mathrm{H}-6_{\mathrm{eq}}\right), 4.32(\mathrm{~m}, 1 \mathrm{H}$, $\mathrm{H}-1), 4.77$ (s, 1H, H-9) $), 4.79$ (s, 1H, H-9 $), 7.12-7.18$ (m, 2H, ArH-2' and ArH-6'), 7.20-7.27 (m, 1H, ArH-4') and 7.29-7.37 (m, 2H, ArH-3' and ArH-5'). ${ }^{13} \mathrm{C}$ NMR: $\delta 15.8$ (C-7), 20.6 (C-10), 37.6 (C-6), 37.7 (C-4), 39.9 (C-5), 71.9 (C-1), 109.3 (C-9), 126.4 (ArC-4'), 128.1 (2C, ArC-3' and ArC-5'), 128.1 (2C, ArC-2' and ArC-6'), 131.1 (C-2), 135.1 (C-3), 142.9 (ArC-1') and 148.7 (C-8).

(1S,5S)-5-Isopropenyl-2-methyl-3-p-tolylcyclohex-2enol 17b: A solution of ketone 16b (241 mg, $1 \mathrm{mmol})$ in THF (5 mL) was transferred to a suspension of $\mathrm{NaBH}_{4}$
(38 mg, $1 \mathrm{mmol}$ ) in a 5:3 THF:MeOH $(8 \mathrm{~mL})$ mixture cooled at $0{ }^{\circ} \mathrm{C}$. After $3 \mathrm{~h}$, acetone $(0.5 \mathrm{~mL})$ was added, the solvent was removed under reduced pressure and the residue was chromatographed, affording alcohol $\mathbf{1 7 b}$ (230 mg, 94\%), as an oil. $[\alpha]_{\mathrm{D}}^{25}+101.6\left(c\right.$ 2.7, $\left.\mathrm{CHCl}_{3}\right)$. IR (film, $v_{\max } / \mathrm{cm}^{-1}$ ): 3340, 2918, 2856, 1643, 1512, 1441, 1039, 972, 888 and 816. ${ }^{1} \mathrm{H}$ NMR: $\delta 1.55-1.70(\mathrm{~m}, 1 \mathrm{H}$, H-6 ${ }_{\mathrm{ax}}$ ), 1.66 (s, H-7), 1.77 (s, 3H, H-10), 2.16-2.46 (m, 7H, $\mathrm{H}-5, \mathrm{H}-4_{\mathrm{ax}}, \mathrm{H}-4_{\mathrm{eq}}$ and $\mathrm{H}-6_{\mathrm{eq}}$ ), 2.38 (s, 3H, ArMe), 4.34 (t, $1 \mathrm{H}, J 7.7, \mathrm{H}-1), 4.76$ (s, $1 \mathrm{H}, \mathrm{H}-9$ ) $), 4.78$ (s, 1H, H-9 $), 7.05$ (d, 2H, J 8.0, ArH-2' and ArH-6') and 7.15 (d, 2H, J 8.0, ArH-3' and ArH-5'). ${ }^{13} \mathrm{C}$ NMR: $\delta 15.8$ (C-7), 20.6 (C-10), 21.0 (ArMe), 37.6 (C-4), ** 37.7 (C-6), ** 39.9 (C-5), 71.9 (C-1), 109.2 (C-9), 128.0 (2C, ArC-2' and ArC-6'), 128.7 (2C, ArC-3' and ArC-5'), 130.9 (C-2), 134.9 (C-3), 136.0 (ArC-1'), 139.9 (ArC-4') and 148.8 (C-8).

(1S,5S)-5-Isopropenyl-2-methyl-(4-methoxyphenyl)cyclohex-2-enol 17c: A solution of ketone 16c $(69 \mathrm{mg}$, $0.27 \mathrm{mmol})$ in THF ( $5 \mathrm{~mL}$ ) was transferred to a suspension of $\mathrm{NaBH}_{4}(20.2 \mathrm{mg}, 0.54 \mathrm{mmol})$ in a 5:3 THF:MeOH $(8 \mathrm{~mL})$ mixture cooled at $0^{\circ} \mathrm{C}$. After $2 \mathrm{~h}$, acetone $(0.5 \mathrm{~mL})$ was added, the solvent was removed under reduced pressure and the residue was chromatographed, affording alcohol $17 \mathrm{c}(58 \mathrm{mg}, 83 \%)$, as a white solid $\mathrm{mp} 94-96{ }^{\circ} \mathrm{C}$ (hexaneEtOAc). $[\alpha]_{\mathrm{D}}{ }^{25}+111.4\left(c 1.21, \mathrm{CHCl}_{3}\right)$. IR $\left(\mathrm{KBr}, v_{\max } / \mathrm{cm}^{-1}\right)$ : 3392, 2913, 1643, 1609, 1512, 1441, 1240, 1173, 1028, 903, 829 and 584. ${ }^{1} \mathrm{H}$ NMR: $\delta 1.64(\mathrm{dt}, 1 \mathrm{H}, J 9.8$ and 12.3, H-6 ${ }_{\mathrm{ax}}$ ), 1.70 (s, 3H, H-7), 1.79 (s, 3H, H-10), 2.17 (dd, $1 \mathrm{H}, J 5.9$ and $\left.12.3, \mathrm{H}-6_{\mathrm{eq}}\right), 2.26-2.53\left(\mathrm{~m}, 3 \mathrm{H}, \mathrm{H}-4_{\mathrm{ax}}, \mathrm{H}-4_{\mathrm{eq}}\right.$ and $\mathrm{H}-5), 3.43$ (s, 3H, OMe), 4.21 (m, 1H, H-1), 4.85 (s, 1H, H-9 $), 4.90$ (s, 1H, H-9 b $_{\mathrm{b}}, 6.89$ (d, 2H, J 8.8, ArH-3' and ArH-5') and 7.14 (d, 2H, J 8.8, ArH-2' and ArH-6'). ${ }^{13}$ C NMR: $\delta 16.3$ (C-7), 20.6 (C-10), 38.4 (C-4), 38.4 (C6), 40.6 (C-5), 54.8 (OMe), 71.9 (C-1), 109.5 (C-9), 114.0 (2C, ArC-3' and ArC-5'), 129.7 (2C, ArC-2' and ArC-6'), 132.2 (C-2), 134.3 (ArC-1'), 135.7 (C-3), 149.0 (C-8) and 158.8 (ArC-4').

( $2 S, 3 R, 5 R)$ - 5 -Is opropenyl-2-methyl-3phenylcyclohexanone 19a: $\mathrm{CuI}(500 \mathrm{mg}, 2.64 \mathrm{mmol})$ was added to a stirred $1.18 \mathrm{M}$ THF solution of $\mathrm{PhMgBr}(8 \mathrm{~mL}$, $5.28 \mathrm{mmol}$ ), cooled to $0^{\circ} \mathrm{C}$. After stirring $15 \mathrm{~min}$, a solution of $(R)$-carvone $(209 \mathrm{mg}, 1.39 \mathrm{mmol})$ and TMSCl $(772 \mathrm{mg}$, $7.1 \mathrm{mmol})$ in THF $(2 \mathrm{~mL})$ was introduced dropwise and the reaction was further stirred $45 \mathrm{~min}$ at $0{ }^{\circ} \mathrm{C}$. Then, the mixture was treated with saturated $\mathrm{NH}_{4} \mathrm{Cl}$ and the reaction products were extracted with EtOAc $(4 \times 50 \mathrm{~mL})$. The combined organic extracts were washed with brine $(10 \mathrm{~mL})$, dried $\left(\mathrm{Na}_{2} \mathrm{SO}_{4}\right)$ and concentrated under reduced pressure. The resulting residue was filtered through a short plug of 
silica gel, furnishing 18a (380 mg, 96\%), as a yellowish oil. Without further purification, a stirred solution of the silyl ether 18a (100 mg, $0.35 \mathrm{mmol})$ in $\mathrm{Et}_{2} \mathrm{O}(10 \mathrm{~mL})$ was cooled to $0^{\circ} \mathrm{C}$ and treated with $1 \mathrm{MTBAF}$ in THF $(0.42 \mathrm{~mL}$, $0.42 \mathrm{mmol}$ ). After $2 \mathrm{~h}$ at this temperature, the volatiles were removed under reduced pressure and the residue was chromatographed affording ketone 19a (72 $\mathrm{mg}, 95 \%)$, as a pale yellow oil. $[\alpha]_{\mathrm{D}}^{25}-55.8\left(c 1.76, \mathrm{CHCl}_{3}\right)$. IR (film, $\left.v_{\max } / \mathrm{cm}^{-1}\right)$ : 2970, 2875, 1709, 1643, 1496, 1377, 1211, 1146, 1030, 900, 756 and 701. ${ }^{1} \mathrm{H}$ NMR: $\delta 0.86$ (d, 3H, $J$ 6.4, H-7), 1.74 (s, 3H, H-10), 2.14 (bdd, 2H, $J 4.6$ and 7.4, H-4), 2.58 (dq, $J 0.8$ and 6.4, H-2), 2.60-2.72 (m, 1H, H-3), 2.64 (dd, 1H, $J 7.7$ and 14.3, H-6 $6_{a x}$ ), 2.74 (bd, 1H, $J$ 14.3, H-6 ${ }_{\mathrm{eq}}$ ), 2.78-2.84 (m, 1H, H-5), 4.77 (s, 1H, H-9 ${ }_{\mathrm{b}}$ ), $4.94(\mathrm{~s}, 1 \mathrm{H}, \mathrm{H}-9$ ) $), 7.19$ (dd, $2 \mathrm{H}, J 1.5$ and 7.2, H-2' and H-6'), 7.18-7.26 (m, 1H, H-4') and 7.32 (dd, 2H, $J 1.5$ and 7.2, $\mathrm{H}-3$ ' and $\mathrm{H}-5$ '). ${ }^{13} \mathrm{C}$ NMR: $\delta 12.4$ (C-7), $22.0(\mathrm{C}-10)$, 35.9 (C-4), 40.9 (C-5), 44.3 (C-6), 46.4 (C-3), 50.1 (C2), 112.6 (C-9), 126.4 (C-4'), 127.1 (2C, C-2' and C-6'), 128.5 (2C, C-3' and C-5'), 143.7 (C-8), ** $146.1\left(\mathrm{C}-1^{\prime}\right)^{* * *}$ and $211.8(\mathrm{C}-1)$.

(2S,3R,5R)-5-Isopropenyl-2-methyl-3-naphthalen1-yl-cyclohexanone 19b: To an ultrasonically irradiated mixture of magnesium turnings (160 mg, $6.67 \mathrm{mmol})$ and a crystal of iodine in dry $\mathrm{Et}_{2} \mathrm{O}(10 \mathrm{~mL})$ under argon was added dropwise a solution of 1-bromonaphthalene $(833 \mathrm{mg}, 3 \mathrm{mmol})$ in anhydrous $\mathrm{Et}_{2} \mathrm{O}(5 \mathrm{~mL})$ over a $30 \mathrm{~min}$ period. During the addition the temperature of the water bath increased due to sonication and maintained the reaction at rapid reflux. After addition was complete, sonication was continued for another $2 \mathrm{~h}$ to ensure complete consumption of the 1-bromonaphthalene. Then, the reaction was cooled to $0^{\circ} \mathrm{C}, \mathrm{CuI}(360 \mathrm{mg}, 1.87 \mathrm{mmol})$ was added, and $15 \mathrm{~min}$ later, the mixture was treated dropwise with a solution of $(R)$-carvone $(282 \mathrm{mg}, 1.82 \mathrm{mmol})$ and TMSCl (204 mg, $1.87 \mathrm{mmol}$ ) in THF (2 mL). After stirring $45 \mathrm{~min}$, the reaction was quenched with saturated $\mathrm{NH}_{4} \mathrm{Cl}(10 \mathrm{~mL})$ and the organic products were extracted with EtOAc $(4 \times 25 \mathrm{~mL})$. The combined organic layers were washed once with brine $(10 \mathrm{~mL})$, drier over $\mathrm{Na}_{2} \mathrm{SO}_{4}$, concentrated under reduced pressure and the remaining oily residue was chromatographed, furnishing $(5 R, 3 S)$ 5-isopropenyl-2-methyl-3-naphthalen-1-yl-cyclohex-1enyloxy)-trimethylsilane (18b, $380 \mathrm{mg}, 96 \%)$, as a yellowish oil. $[\alpha]_{\mathrm{D}}{ }_{\mathrm{D}}^{25}-32.9\left(c 0.85, \mathrm{CHCl}_{3}\right.$ ). IR (film, $\left.\mathrm{v}_{\max } / \mathrm{cm}^{-1}\right)$ : 3066, 2959, 2857, 1685, 1508, 1448, 1337, 1252, 1187, 1063, 929, 842, and 779. ' $\mathrm{H}$ NMR: $\delta 0.35$ (s, 3H, $\mathrm{Me}_{3} \mathrm{Si}$ ), 1.61 (s, 3H, Me-7), 1.64 (s, 3H, Me-10), 1.90-2.10 (m, 2H, H-4), 2.10-2.25 (m, 1H, H-6), 2.26-2.38 (m, 2H, H-5 and H-6), 4.32 (bd, 1H, J 1.2, H-3), 4.64 (d, 1H, J 1.5, H-9),
4.66, d, 1H, J 1.5, H-9), 7.36 (dd, 1H, $J 1.1$ and 7.1, H-2'), 7.42-7.61 (m, 3H, H-6' and H-7'), 7.77 (d, 1H, J 8.1, H-4'), 7.89 (dd, $1 \mathrm{H}, J 3.3$ and 6.2, H-3'), 7.92 (dd, $1 \mathrm{H}, J 1.4$ and 8.1, H-5') and $8.20\left(\mathrm{~d}, 1 \mathrm{H}, J\right.$ 8.3, H-8'). ${ }^{13} \mathrm{C}$ NMR: $\delta 1.0$ (3C, $\mathrm{Me}_{3} \mathrm{Si}$ ), 15.6 (C-7), 20.8 (C-10), 34.3 (C-4), 36.0 (C-6), 37.1 (C-5), 41.3 (C-3), 109.0 (C-9), 112.4 (C-2), 123.4 (C-8'), 125.2 (C-6'), 125.9 (2C, C-7' and C-2'), 126.8 (C-4'), 127.9 (C-3'), 129.0 (C-5'), 132.0 (C-4a'), 134.3 (C-8a'), 139.9 (C-1'), 146.1 (C-1) and 146.9 (C-8). Without further purification, a solution of silyl ether $\mathbf{1 8 b}$ $(140 \mathrm{mg}, 0.40 \mathrm{mmol})$ in $\mathrm{Et}_{2} \mathrm{O}(20 \mathrm{~mL})$ was treated with a $1 \mathrm{M}$ solution of TBAF in THF $(0.48 \mathrm{~mL}, 0.48 \mathrm{mmol})$ and the resulting mixture was stirred $2 \mathrm{~h}$ at room temperature. Then, brine $(10 \mathrm{~mL})$ was added and the organic products were extracted with EtOAc $(4 \times 15 \mathrm{~mL})$. The combined organic extracts were washed with brine $(1 \times 10 \mathrm{~mL})$, drier $\left(\mathrm{Na}_{2} \mathrm{SO}_{4}\right)$ and concentrated under reduced pressure. The residue was chromatographed, furnishing 19b (100 mg, 90\%) as a solid, $\mathrm{mp} 77-79^{\circ} \mathrm{C}$ (hexane-EtOAc). $[\alpha]_{\mathrm{D}}^{25}-19.9\left(c 1.10, \mathrm{CHCl}_{3}\right.$ ). IR (film, $\left.v_{\max } / \mathrm{cm}^{-1}\right): 3058$, 2966, 2863, 1703, 1641, 1510, 1448, 1376, 1213, 1141, 906, 800 and 783. ${ }^{1} \mathrm{H}$ NMR: $\delta 0.93$ (d, 3H, J 6.5, H-7), 1.79 (s, 3H, H-10), 2.10-2.25 (m, 2H, H-4), 2.71 (dd, 1H, J 6.9 and 15.1, H- $6_{\mathrm{ax}}$ ), 2.78-2.84 (bs, 3H, H-2, H-5 and H- $6_{\mathrm{eq}}$ ), 3.74 (bt, J3.2 and 7.8, 1H, H-3), 4.87 (s, 1H, H-9 $\mathrm{a}_{\mathrm{a}}, 5.05$ (s, 1H, H-9 $)$ ), 7.44-7.55 (m, 4H, H-2', H-3', H-6' and H-7'), 7.75 (d, 1H, $\left.J 6.3, \mathrm{H}-4^{\prime}\right), 7.88$ (dd, $1 \mathrm{H}, J 2.9$ and 6.6, H-5') and $8.00\left(\mathrm{~d}, 1 \mathrm{H}, J 8.8, \mathrm{H}-8\right.$ '). ${ }^{13} \mathrm{C}$ NMR: $\delta 13.0(\mathrm{C}-7), 22.3$ (C-10), 36.0 (C-4), 39.6 (C-3), 41.3 (C-5), 44.7 (C-6), 50.3 (C-2), 112.9 (C-9), 122.4 (C-8'), 123.3 (C-2'), 125.6 (2C, C-6' and C-7'), 126.2 (C-3'), 127.0 (C-4'), 129.1 (C-5'), 131.9 (C-8a'), 134.0 (C-4a'), 140.0 (C-1'), 146.7 (C-8) and $212.8(\mathrm{C}-1)$.

(1R-2S,3R,5R)-5-Isopropenyl-2-methyl-3phenylcyclohexanol 20a: A stirred solution of ketone 19a $(70 \mathrm{mg}, 0.31 \mathrm{mmol})$ in THF $(5 \mathrm{~mL})$, was cooled to $-78{ }^{\circ} \mathrm{C}$ and treated dropwise with a $0.5 \mathrm{~mol} \mathrm{~L}^{-1}$ solution of K-Selectride ( $0.94 \mathrm{~mL}, 0.47 \mathrm{mmol})$. Stirring continued for $2 \mathrm{~h}$, when acetone was added to destroy the unreacted reducing agent. The mixture was left to attain room temperature, brine $(10 \mathrm{~mL})$ was added and the reaction products were extracted with EtOAc $(4 \times 15 \mathrm{~mL})$. The organic phases were combined, washed with brine $(5 \mathrm{~mL})$ and dried over $\mathrm{Na}_{2} \mathrm{SO}_{4}$. After removal of the solvent under reduced pressure, the residue was chromatographed, affording alcohol 20a (56 mg, 80\%), as an oil. $[\alpha]_{\mathrm{D}}{ }^{25}-36.3$ (c 1.13, $\mathrm{CHCl}_{3}$ ). IR (film, $v_{\max } / \mathrm{cm}^{-1}$ ): 3415, 2935, 2874, 1650, 1495, 1447, 1066, 889 and 699. ${ }^{1} \mathrm{H}$ NMR: $\delta 0.87$ (d, 3H, J 6.9, H-7), 1.71 (bs, $\left.1 \mathrm{H}, w_{1 / 2}=13, \mathrm{OH}\right), 1.75-2.25$ (m, 5H, H-4, H-2 and H-6), 1.87 (s, 3H, H-10), 2.38 (bdd, 
$1 \mathrm{H}, J 4.9$ and 9.7, $\mathrm{H}-5), 2.90$ (dt, $1 \mathrm{H}, J 3.9$ and 13.9, H-3), 3.90 (dt, $1 \mathrm{H}, J 4.5$ and 5.9, H-1), 4.92 (s, 1H, H-9a), 5.01 (s, 1H, H-9b) and 7.15-7.40 (m, 5H, ArH). ${ }^{13} \mathrm{C}$ NMR: $\delta$ 15.4 (C-7), 22.4 (C-10), 34.2 (C-4 and C-6), 38.2 (C-5), 40.6 (C-2), 41.6 (C-3), 71.8 (C-1), 109.7 (C-9), 126.0 (C-4'), 127.4 (2C, C-2' and C-6'), 128.4 (2C, C-3' and C-5'), 145.2 (C-1') and 149.7 (C-8).

(1R,2S,3R,5R)-5-Isopropenyl-2-methyl-3-naphthalen1-yl-cyclohexanol 20b: A solution of ketone 19b (98 mg, $0.35 \mathrm{mmol})$ in THF $(5 \mathrm{~mL})$, was cooled to $-78{ }^{\circ} \mathrm{C}$ and treated with K-Selectride $(2.1 \mathrm{~mL}, 1.06 \mathrm{mmol})$. After $2 \mathrm{~h}$, acetone was added to destroy the unreacted reducing agent and the solution was warmed to room temperature. Then, the solvent was removed under reduced pressure and the residue was chromatographed, furnishing $\mathbf{2 0 b}$ (71 mg, 80\%), as a solid $\mathrm{mp} 57-59{ }^{\circ} \mathrm{C}$ (hexane-EtOAc). $[\alpha]_{\mathrm{D}}^{25}-88.0\left(\mathrm{c} 0.75, \mathrm{CHCl}_{3}\right)$. IR (film, $\left.v_{\max } / \mathrm{cm}^{-1}\right): 3416$, 2960, 2873, 1642, 1597, 1449, 1396, 1119, 1009, 890, 778 and 733. ${ }^{~} \mathrm{H}$ NMR: $\delta 0.89$ (d, 3H, J 6.8, H-7), 1.75-1.90 (m, $1 \mathrm{H}, \mathrm{H}-2$ ) , 1.90 (ddd, 1H, J3.3, 5.8 and 14.0, $\mathrm{H}-6_{\mathrm{ax}}$ ), 1.94 (s, $3 \mathrm{H}, \mathrm{H}-10), 1.96$ (ddd, 1H, J 5.0, 9.6 and 14.6, H-4 ${ }_{\mathrm{ax}}$ ), 2.15 (ddd, 1H, J 3.1, 7.0 and 9.0, H-3), 2.21 (ddt, $1 \mathrm{H}, J 1.7,4.7$ and $\left.14.5, \mathrm{H}-4_{\mathrm{eq}}\right), 2.32$ (ddt, $1 \mathrm{H}, J 1.7,5.3$ and 14.0, $\mathrm{H}-6_{\mathrm{eq}}$ ), $2.54(\mathrm{dt}, 1 \mathrm{H}, J 5.0$ and $10.0, \mathrm{H}-\mathrm{x}), 3.85(\mathrm{dt}, 1 \mathrm{H}, J 4.3$ and 9.2, H-1), 4.00 (bs, 1H, OH), 5.00 (s, 1H, H-9), 5.14 (s, 1H, H-9), 7.44-7.56 (m, 4H, H-2', H-3', H-6' and H-7'), 7.74 (dd, $1 \mathrm{H}, J 2.9$ and 6.3, H-4'), 7.88 (dd, $1 \mathrm{H}, J 1.7$ and 7.9, $\left.\mathrm{H}-5^{\prime}\right)$ and 8.17 (d, $1 \mathrm{H}, J$ 8.0, H-8'). ${ }^{13} \mathrm{C}$ NMR: $\delta 15.4$ (C-7), 22.6 (C-10), 34.2 (C-6), 34.8 (C-4), 35.4 (C-3), 38.8 (C-2), 41.9 (C-5), 72.3 (C-1), 109.7 (C-9), 123.3 (C-8'), $123.5\left(\mathrm{C}-2^{\prime}\right),{ }^{*} * 125.4\left(\mathrm{C}-6\right.$ '), ** $125.6\left(\mathrm{C}^{\prime} 3^{\prime}\right)$, ** 125.9 (C-7'),** 126.6 (C-4'), 129.1 (C-5'), 132.3 (C-8a'), 134.1 (C-4a'), 142.2 (C-1') and 150.0 (C-8).

Typical procedure for the preparation of ( \pm )-ibuprofen esters under Steglich conditions: A solution of DCC (1.0 equiv.) in the reaction solvent $(0.5 \mathrm{~mL})$ was added to a mixture of the chiral auxiliary ( $20 \mathrm{mg}, 1.0$ equiv.), $( \pm)$-ibuprofen (1.0 equiv.) and DMAP (1.0 equiv.), dissolved in the reaction solvent $(3 \mathrm{~mL})$. The reaction was stirred (0.5-3 days) at the designated temperature until complete, then the solvent was removed under reduced pressure and the residue was chromatographed.

$(1 S, 2 S, 2$ " $R, 3 R, 5 S)$ - and ( $1 S, 2 S, 2$ " $S, 3 R, 5 S)-2-(4-$ Isobutylphenyl)-propionic acid 5-isopropenyl-2-methyl3-phenylsulfanyl-cyclohex-1-yl ester 21a,b: Oil. Yield = 95\%. $[\alpha]_{\mathrm{D}}^{25}-39.3\left(\mathrm{c} 0.31, \mathrm{CHCl}_{3}\right)$. IR (film, $\left.v_{\max } / \mathrm{cm}^{-1}\right)$ : 2954, 2927, 2869, 1730, 1451, 1247, 1165, 1050, 887 and 692. Major diastereomer, $(1 S, 2 S, 2 " R, 3 R, 5 S)-21$ : ${ }^{1} \mathrm{H}$ NMR: $\delta 0.88\left(\mathrm{~d}, 6 \mathrm{H}, J\right.$ 6.6, $\left.\mathrm{ArCH}_{2} \mathrm{CHMe} e_{2}\right) .0 .99$ (d, 3H, J 6.9, $\mathrm{H}-7$ ), 1.41 (ddd, $1 \mathrm{H}, J$ 2.6, 11.7 and 14.3, H-6), 1.52-1.58 (m, 1H, H-4), 1.61(d, 3H, J 7.3, ArCHMe), 1.63 (s, 3H, $\mathrm{H}-10$ ), 1.83 (septet, $1 \mathrm{H}, J \mathrm{ArCH}_{2} \mathrm{CHMe}_{2}$ ), 1.86-1.94 (m, 1H, H-6), 1.97-2.02 (m, 1H, H-4), 2.03-2.11 (m, 1H, H-2), $2.44\left(\mathrm{~d}, 2 \mathrm{H}, J\right.$ 7.3, $\left.\mathrm{ArCH}_{2} \mathrm{CHMe}_{2}\right), 2.66$ (tt, $1 \mathrm{H}, J 5.9$ and 11.5, H-5), 3.40 (dd, 1H, J 4.3 and 8.4, H-3), 3.79 (q, $1 \mathrm{H}$, J 7.3, $\mathrm{ArCHMe}$ ), 4.65 (s, 1H, H-9), 4.70 (s, 1H, H-9), 5.00 (dd, $1 \mathrm{H}, J 3.2$ and 6.6, H-1), 7.10 (d, 2H, J 8.0, H-3"' and H-5"'), 7.18-7.22 (m, 1H, H-4'), 7.24-7.32 (m, 2H, H-3' and H-5'), 7.36 (d, 2H, J 8.0, H-2"' and H-6"') and 7.40 (dd, $2 \mathrm{H}, J 1.2$ and 8.1, H-2"' and H-6"'). ${ }^{13} \mathrm{C}$ NMR: $\delta 15.7$ (C7), 18.0 ( $\mathrm{ArCHMe}$ ), 21.2 (C-10), 22.3 (2C, $\mathrm{ArCH}_{2} \mathrm{CHMe}$ ), $30.2\left(\mathrm{ArCH}_{2} \mathrm{CHMe}_{2}\right.$ ), 33.7 (H-5), 34.7 (H-6), 36.3 (H-4), 37.9 (H-2), $45.1\left(\mathrm{ArCH}_{2}\right), 46.0$ (ArCHMe), 51.4 (C-3), 72.9 (H-1), 109.2 (C-9), 126.5 (C-4 PhS), 127.5 (2C, C-2"' and C-6"'), 128.9 (C-3' and C-5'), 129.2 (C-3"' and C-5”'), 131.5 (2C, C-2' and C-6'), 137.7 (C-1'), 138.0 (C1"'), 140.5 (C-4"'), $148.6(\mathrm{C}-8)$ and $174.4(\mathrm{C}=\mathrm{O})$. Minor diastereomer, $(1 S, 2 S, 2$ " $S, 3 R, 5 S)$-21: ${ }^{1} \mathrm{H}$ NMR: $\delta 0.89(\mathrm{~d}$, $6 \mathrm{H}, J$ 6.6, $\left.\left.\mathrm{ArCH}_{2} \mathrm{CHMe}\right)_{2}\right) .1 .15$ (d, 3H, J 6.9, H-7), 1.451.60 (m, 2H, H-4 and H-6), 1.61(d, 3H, J 7.3, ArCHMe), 1.71 (s, 3H, H-10), 1.83 (septet, $1 \mathrm{H}, J \mathrm{ArCH}_{2} \mathrm{CHMe}_{2}$ ), 1.86-1.94 (m, 1H, H-6), 1.97-2.02 (m, 1H, H-4), 2.03-2.11 (m, 1H, H-2), 2.44 (d, 2H, J 7.3, $\mathrm{ArCH}_{2} \mathrm{CHMe}_{2}$ ), 2.66 (tt, $1 \mathrm{H}, J 5.9$ and $11.5, \mathrm{H}-5$ ), 3.38 (dd, $1 \mathrm{H}, J 4.3$ and $8.4, \mathrm{H}-3$ ), 3.79 (q, 1H, J 7.3, ArCHMe), 4.55 (s, 1H, H-9), 4.65 (s, 1H, H-9), 5.00 (dd, 1H, J 3.2 and 6.6, H-1), 7.10 (d, 2H, $J$ 8.0, H-3"' and H-5"'), 7.18-7.22 (m, 1H, H-4'), 7.247.32 (m, 2H, H-3' and H-5'), 7.36 (d, 2H, J 8.0, H-2"' and H-6"') and 7.40 (dd, 2H, J 1.2 and 8.1, H-2"' and H-6"'). ${ }^{13} \mathrm{C}$ NMR: $\delta 14.1$ (C-7), 17.9 (ArCHMe), 21.1 (C-10), 22.3 $\left(2 \mathrm{C}, \mathrm{ArCH}_{2} \mathrm{CHMe} e_{2}\right), 29.4\left(\mathrm{ArCH}_{2} \mathrm{CHMe}_{2}\right), 31.9$ (H-5), 34.0 (H-6), 36.3 (H-4), 37.9 (H-2), $45.4\left(\mathrm{ArCH}_{2}\right), 45.5$ (ArCHMe), 51.4 (C-3), 73.3 (H-1), 109.0 (C-9), 125.5 (C-4 PhS), 127.2 (2C, C-2"' and C-6"'), 128.9 (C-3' and C-5'), 129.2 (C-3"' and C-5"'), 131.4 (2C, C-2' and C-6'), 137.7 (C-1'), 138.0 (C-1"'), 140.4 (C-4"”), 148.5 (C-8) and $174.4(\mathrm{C}=\mathrm{O})$.

$(1 S, 2 S, 2$ " $R, 3 S, 5 S)$ and $(1 S, 2 S, 2$ " $S, 3 S, 5 S)-2-(4-$ Isobutylphenyl)-propionic acid 5-isopropenyl-2-methyl3-phenylsulfanyl-cyclohexyl ester 22a,b: Yield $=65 \%$. IR (film, $v_{\text {max }} / \mathrm{cm}^{-1}$ ): 3436, 2954, 1728, 1452, 1166, 890, 743 and $692 \mathrm{~cm}^{-1}$. ${ }^{1} \mathrm{H}$ NMR: $\delta 0.86$ (d, 6H, $J 6.6, \mathrm{H}-9$ '”), 1.10 and $1.21(\mathrm{~d}, 3 \mathrm{H}, J 6.8, \mathrm{H}-7), 1.16-1.38(\mathrm{~m}, 2 \mathrm{H}, \mathrm{H}-4$ ax and $\mathrm{H}-6_{\mathrm{ax}}$ ), 1.47 and 1.59 (s, 3H, H-10), 1.49-1.55 (m, 4H, H-2" and H-3"), 1.69-2.17 (m, 5H, H-4 ${ }_{\text {eq' }}$ H-5, H-6 $6_{\text {eq }}$ and H-8"'), 2.42 and 2.46 (d, 2H, J 7.0, H-7"' ), 2.92 and $2.94(\mathrm{dt}, 1 \mathrm{H}$, $J$ 3.9, and 11.9, H-3), 3.72 and 3.73 (q, 1H, $J$ 7.2, H-2), 4.44 and 4.57 (s, 1H, H-9 $), 4.57$ and 4.65 (s, 1H, H-9 ${ }_{\mathrm{a}}$ ), 
5.05 and 5.07 (dd, 1H, J 2.8 and 5.6, H-1), 7.07-7.12 (m, 2H, ArH-3' and ArH-3') and 7.16-7.41 (m, 7H, ArH-2', ArH-4', ArH-6', ArH-2"', ArH-3"', ArH-5"' and ArH-6"'). ${ }^{13}$ C NMR: $\delta 16.1$ and 16.4 (C-7), 17.6 and 17.6 (C-3"), 20.4 and 20.5 (C-10), 22.2 (2C, C-9"'), 30.1 (C-8"'), 35.0 and $35.2(\mathrm{C}-4), 38.7$ and 39.0 (C-5), 39.1 and 39.3 (C-6), 39.7 and 40.0 (C-2), 44.9 (C-7"'), 45.2 and 45.6 (C-2"), 48.9 and 49.0 (C-3), 74.2 and 74.4 (C-1), 108.9 and 109.2 (C-9), 126.8 and 126.9 (ArC-4'), 127.0 and 127.1 (2C, ArC-2"' and ArC-6"'), 128.6 and 128.7 (2C, ArC-3"' and ArC-5"'), 129.1 and 129.2 (2C, ArC-3' and ArC-5'), 132.4 (2C, ArC-2' and ArC-6'), 134.3 and 134.4 (ArC-1'), 137.6 and 137.7 (ArC-1"'), 140.4 and 140.5 (ArC-4"'), 148.1 and $148.1(\mathrm{C}-8)$, and 173.8 and $173.8(\mathrm{C}=\mathrm{O})$.

$(1 S, 2 S, 2 " R, 3 R, 5 S)$ - and $(1 S, 2 S, 2$ " $S, 3 R, 5 S)-2-(4-$ Isobutylphenyl)-propionic acid 5-isopropenyl-2-methyl-3(naphthalen-2-ylsulfanyl)-cyclohex-1-yl ester 23a,b: Oil. Yield $=69 \% \cdot[\alpha]_{\mathrm{D}}^{25}+53.2\left(c 0.27, \mathrm{CHCl}_{3}\right) \cdot \mathrm{IR}\left(\right.$ film, $\left.v_{\max } / \mathrm{cm}^{-1}\right)$ : $3435,2955,2927,1729,1646,1453,1247,1165$, $1050,887,849,814$ and 744. Major diastereomer, $(1 S, 2 S, 2 " R, 3 R, 5 S)$-23: ${ }^{1} \mathrm{H}$ NMR: $\delta 0.88(\mathrm{~d}, 6 \mathrm{H}, J 6.6$, $\mathrm{ArCH}_{2} \mathrm{CHMe}$ ), 1.03 (d, 3H, J 7.0, H-7), 1.43 (ddd, 1H, $J$ 2.7, 11.7 and 14.2, H-6), 1.52-1.62 (m, 1H, H-4), 1.63 (d, 3H, J 7.3, ArCHMe), 1.64 (s, 3H, H-10), 1.84 (septet, 1H, $J$ 6.6, $\mathrm{ArCH}_{2} \mathrm{CHMe}$ ), 1.90-1.98 (m, 1H, H-6), 2.02-2.08 (m, 1H, H-4), 2.09-2.15 (m, 1H, H-2), 2.45 (d, 2H, J 7.2, $\mathrm{ArCH}_{2} \mathrm{CHMe}_{2}$ ), 2.70 (tt, $1 \mathrm{H}, J 5.9$ and 11.5, H-5), 3.55 (dd, $1 \mathrm{H}, J 3.8$ and 8.0, H-3), 3.81 (q, 1H, J 7.3, ArCHMe), 4.66 (s, 1H, H-9), 4.70 (s, 1H, H-9), 5.04 (dd, 1H, J 3.1 and 6.3, H-1), 7.11 (d, 2H, J 8.0, H-3"' and H-5"'), 7.43-7.51 (m, 3H, Naphth), 7.38 (d, 2H, J 8.0, H-2"' and H.6"') and 7.77-7.84 (m, 4H, Naphth). ${ }^{13} \mathrm{C}$ NMR: $\delta 15.8$ (C-7), 18.0 ( $\mathrm{ArCHMe}$ ), 21.3 (C-10), 22.4 (2C, $\left.\mathrm{ArCH}_{2} \mathrm{CHMe} e_{2}\right), 30.2$ $\left(\mathrm{ArCH}_{2} \mathrm{CHMe}_{2}\right.$ ), 33.8 (H-5), 34.8 (H-6), 36.3 (H-4), 37.95 (H-2), $45.1\left(\mathrm{ArCH}_{2}\right), 46.0$ (ArCHMe), 51.1 (C-3), 72.9 (H-1), 109.3 (C-9), 125.8 (Naphth), 126.4 (Naphth), 127.2 (Naphth), 127.6 (2C, C-2"' and C-6"'), 127.7 (Naphth), 128.4 (Naphth), 129.2 (4C, $2 \times$ Naphth, C-3"' and C-5"'), 132.0 (Naphth-8'), * 133.8 (Naphth-4'), * 135.4 (C-1' Naphth),* 137.7 (C-1"'), 140.5 (C-4"”), 148.6 (C-8) and $174.4(\mathrm{C}=\mathrm{O})$. Minor diastereomer, $(1 S, 2 S, 2$ " $S, 3 R, 5 S)-\mathbf{2 3}$ : ${ }^{1} \mathrm{H}$ NMR: $\delta 0.89$ (d, 6H, J 6.6, $\mathrm{ArCH}_{2} \mathrm{CHMe}$ ), 1.19 (d, 3H, $J$ 7.0, H-7), 1.43 (ddd, $1 \mathrm{H}, J 2.7,11.7$ and 14.2, H-6), 1.521.62 (m, 1H, H-4), 1.61 (d, 3H, J 7.3, ArCHMe), 1.64 (s, 3H, $\mathrm{H}-10$ ), 1.84 (septet, $1 \mathrm{H}, J$ 6.6, $\mathrm{ArCH}_{2} \mathrm{CHMe}_{2}$ ), 1.90-1.98 (m, 1H, H-6), 2.02-2.08 (m, 1H, H-4), 2.09-2.15 (m, 1H, $\mathrm{H}-2$ ), 2.46 (d, 2H, J 7.2, $\mathrm{ArCH}_{2} \mathrm{CHMe}_{2}$ ), 2.70 (tt, 1H, J 5.9 and 11.5, H-5), 3.56 (dd, $1 \mathrm{H}, J 3.8$ and 8.0, H-3), 3.83 (q, 1H, J 7.3, ArCHMe), 4.56 (s, 1H, H-9), 4.64 (s, 1H, H-9), 4.96 (dd, 1H, J 3.1 and 6.3, H-1), 7.12 (d, 2H, J 8.0, H-3"' and H-5"'), 7.43-7.51 (m, 3H, Naphth), 7.38 (d, 2H, J 8.0, H-2"" and H.6"') and 7.77-7.84 (m, 4H, Naphth).

$(1 S, 2 S, 2$ " $R, 3 S, 5 S)$ - and (1S, 2S, 2" $S, 3 S, 5 S)-2-(4-$ Isobutylphenyl)-propionic acid 5-isopropenyl-2-methyl3-phenylsulfonyl-cyclohexyl ester 24a,b: Yield $=95 \%$. IR (film, $v_{\max } / \mathrm{cm}^{-1}$ ): 2954, 1731, 1447, 1305, 1145, 1085 and $691 \mathrm{~cm}^{-1} .{ }^{1} \mathrm{H}$ NMR: $\delta 0.85$ and 0.87 (d, 6H, $J$ 6.7, H-9"'), 0.94 and 1.01 (d, 3H, J 6.7, H-7), 1.08-1.27 (m, 2H, H-4 ax and $\left.\mathrm{H}-6_{\mathrm{ax}}\right), 1.42$ and 1.46 (d, 3H, J 7.2, H-3"), 1,54 and 1.56 (s, 3H, H-10), 1.68-1.93 (m, 4H, H- $4_{\text {eq }}, \mathrm{H}-5, \mathrm{H}-6_{\text {eq }}$ and H-8"'), 1.94-2.05 (m, 1H, H-2), 2.41 and 2.44 (d, 2H, J 7.2, H-7"'), 3.04 and 3.06 (ddd, $1 \mathrm{H}, J 3.5,11.2$ and 12.6, H-3), 3,71 (q, 1H, J 7.2, H-2"), 4.38 and 4.53 (s, 1H, H-9 b $^{\text {) }} 4.57$ and 4.66 (s, 1H, H-9) , 4.96-5.03 (m, 1H, H-1), 7.04-7.22 (m, 4H, ArH-2"', ArH-3"', ArH-5"' and ArH-6"'), 7.527.70 (m, 3H, ArH-3', ArH-4' and ArH-5') and 7.80-7.88 (m, 2H, ArH-2' and ArH-6'). ${ }^{13} \mathrm{C}$ NMR: $\delta 16.8$ and 17.1 (C-7), 17.6 and 17.7 (C-3"), 20.1 and 20.2 (2C, C-9"'), 20.3 and 20.4 (C-10), 30.1 and 30.3 (C-8"'), 31.9 (C-4), 34.4 and 34.6 (C-6), 35.4 and 35.6 (C-5), 37.1 and 37.4 (C-2"), 44.9 (C-7"'), 45.0 and 45.5 (C-2), 64.5 (C-3), 74. 8 and 74.9 (C-1), 109.6 and 109.9 (C-9), 126.9 and 127.0 (2C, ArC-2"' and ArC-6"'), 128.4 and 128.5 (2C, ArC-2' and ArC-6'), 129.0 (2C, ArC-3' and ArC-5'), 129.2 and 129.3 (2C, ArC-3"' and ArC-5"'), 133.5 (ArC-4'), 137.3 and 137.8 (ArC-1"'), 138.1 and 138.2 (ArC-1'), 140.5 and 140.6 (ArC-4"'), 147.0 and $147.1(\mathrm{C}-8)$ and $173.6(\mathrm{C}=\mathrm{O})$.

$(1 S, 2 S, 2$ " $R, 3 S, 5 S)$ - and (1S, 2S, 2" $S, 3 S, 5 S)-2-(4-$ Isobutylphenyl)-propionic acid 5-isopropenyl-2-methyl3-phenylsulfinyl-cyclohexyl ester 25a,b: Yield $=81 \%$. IR (film, $v_{\max } / \mathrm{cm}^{-1}$ ): 2954, 1732, 1444, 1168, 1088, 1045 and $750 \mathrm{~cm}^{-1} .{ }^{~}{ }^{\mathrm{H}} \mathrm{NMR}: \delta 0.81$ and 0.87 (d, 6H, $J$ 6.6, H-9"'), 0.99 and 1.27 (d, 3H, $J$ 6.7, H-7), 0.99-1.40 (m, 3H, H-4 ${ }_{2 x}$, H-6 $6_{\text {ax }}$ and H-8"'), 1.51 and 1.53 (d, 3H, J 7.2, H-3"), 1.40 and 1.53 (s, 3H, H-10), 1.53-2.16 (m, 4H, H-2, H- ${ }_{\text {eq }}$, H-5 and $\mathrm{H}-6_{\mathrm{eq}}$ ), 2.23 and 2.30 (ddd, $1 \mathrm{H}, J 3.5,11.8$ and 11.9, H-3), 2.39 and 2.46 (d, 2H, $J$ 7.2, H-7"'), 3.70 and 3.72 (q, 1H, J 7.6, H-2"), 4.40 and 4.55 (s, 1H, H-9) 4.53 and 4.62 (s, 1H, H-9 $)$, 5.11-5.21 (m, 1H, H-1), 7.01-7.24 (m, 5H, ArH-3', ArH-4', ArH-5', ArH-2"' and ArH-6"') and 7.40-7.61 (m, 4H, ArH-2', ArH-6', ArH-3"' and ArH-5"'). ${ }^{13}$ C NMR: $\delta 15.4$ and 15.8 (C-7), 17.5 and 17.6 (C-3"), 20.1 and 20.2 (C-10), 22.2 (2C, C-9"'), 23.8 and 23.9 (C4), 30.0 and 30.1 (C-8"'), 34.5 (C-6), 34.8 and 35.1 (C-5), 37.2 and 37.6 (C-2"), 44.8 and 44.9 (C-7"'), 45.1 and 45.4 (C-2), 64.2 (C-3), 74.1 and 74.4 (C-1), 109.5 and 109.8 (C-9), 124.1 and 124.2 (2C, ArC-2' and ArC-6'), 127.0 and 127.2 (2C, ArC-2"' and ArC-6"'), 129.2 (2C, ArC-3"' and ArC-5”'), 129.9 (2C, ArC-3' and ArC-5'), 130.3 (ArC-4'), 
137.7 and 137.8 (ArC-1"'), 140.5 and 140.6 (ArC-4"'), 141.1 and 141.2 (ArC-1'), 147.6 and 147.7 (ArC-8), and 173.5 and $173.6(\mathrm{C}=\mathrm{O})$.

(1S,2"R,5S)- and (1S,2"S,5S)-2-(4-Isobutylphenyl)propionic acid 5-isopropenyl-2-methyl-3-phenyl-cyclohex2-enyl ester 26a, $\boldsymbol{b}$ : Oil. Yield $=40 \%$. $[\alpha]_{\mathrm{D}}{ }^{25}+81.0(c 0.65$, $\mathrm{CHCl}_{3}$ ). IR (film, $v_{\text {max }} / \mathrm{cm}^{-1}$ ): 2924, 1729, 1513, 1450, 1375, $1190,956,890$ and 798. Major diastereomer, $(1 S, 2 " S, 5 S)-26$ ${ }^{1} \mathrm{H}$ NMR: $\delta 0.85$ (d, 6H, J 6.6, $\mathrm{ArCH}_{2} \mathrm{CHMe}$ ) 1.15 (s, 3H, $\mathrm{H}-7$ ), 1.50-1.64 (m, 4H, H-6 ax $\mathrm{ax}-3$ ”), 1.73 (s, 3H, H-10), 1.81 (tq, $1 \mathrm{H}, J 6.6$ and 7.0, H-8"'), 2.08-2.34 (m, 3H, H-4 ${ }_{\text {ax }}$, $\mathrm{H}-4_{\text {eq }}$ and $\left.\mathrm{H}-6_{\mathrm{eq}}\right), 2.34-2.51$ (m, 3H, H-5 and H-7"'), 3.72 (q, 1H, J 7.1, H-2"), 4.74 (m, 2H, H-9 and $\mathrm{H}-9$ ) $), 5.48-$ $5.62(\mathrm{~m}, 1 \mathrm{H}, \mathrm{H}-1), 7.02-7.11(\mathrm{~m}, 4 \mathrm{H}, \mathrm{ArH})$ and 7.17-7.37 (m, 5H, ArH). ${ }^{13} \mathrm{C}$ NMR: $\delta 15.1$ (C-7), 18.1 (ArCHMe), 20.4 (C-10), 22.2 (2C, C-9"'), $30.1\left(\mathrm{ArCH}_{2} \mathrm{CHMe}_{2}\right), 33.8$ (C-6), 37.4 (C-4), 39.9 (C-5), 44.9 ( $\left.\mathrm{ArCH}_{2} \mathrm{CHMe}_{2}\right) 45.4$ (ArCHMe), 74.4 (C-1), 109.4 (C-9), 126.4 (ArC-4'), 127.1 (2C, ArC-2"' and ArC-6"'), 128.0 (2C, ArC-3' and Ar-5'), 128.0 (2C, ArC-2' and ArC-6'), 128.3 (C-2), 129.1 (2C, ArC-3"' and ArC-5"'), 136.5 (ArC-1"'), 137.8 (ArC-4"'), 140.4 (ArC-1'), 142.5 (C-3), 147.9 (C-8) and $174.4(\mathrm{C}=\mathrm{O})$. Minor diastereomer, $(1 S, 2 " R, 5 S)$-26: ${ }^{1} \mathrm{H}$ NMR: $\delta 0.88$ (d, $6 \mathrm{H}, J$ 6.6, $\mathrm{ArCH}_{2} \mathrm{CHMe}$ ), 1.44 (s, 3H, H-3"), 1.53 (d, 3H, $J$ 7.2, H-7), 1.69 (s, 3H, H-10), 1.84 (tq, $1 \mathrm{H}, J 6.6$ and 7.0, H-8”'), 2.08-2.33 (m, 3H, H-4 ${ }_{\text {ax }}, \mathrm{H}-4_{\text {eq }}$ y H-6 ${ }_{\text {eq }}$ ), 2.33-2.51 (m, 4H, H-5, H-6 ax and H-7"'), 3.75 (q, 1H, J 7.1, H-2"), 4.69 (s, 1H, H-9 $\left.{ }_{\mathrm{a}}\right), 4.71$ (s, 1H, H-9 $), 5.48-5.62(\mathrm{~m}, 1 \mathrm{H}$, $\mathrm{H}-1)$, 7.02-7.17 (m, 4H, ArH) and 7.17-7.37 (m, 5H, ArH). ${ }^{13}$ C NMR: $\delta 15.51$ (C-7), 18.36 (ArCHMe), 20.41 (C-10), 22.19 (2C, C-9"'), $30.08\left(\mathrm{ArCH}_{2} \mathrm{CHMe}_{2}\right), 33.4$ (C-6), 37.4 (C-4), 39.8 (C-5), $44.9\left(\mathrm{ArCH}_{2} \mathrm{CHMe}_{2}\right) 45.4$ ( $\left.\mathrm{ArCHMe}\right)$, 74.3 (C-1), 109.4 (C-9), 126.5 (ArC-4'), 127.1 (2C, ArC-2"' and ArC-6"'), 128.0 (2C, ArC-3' and ArC-5'), 128.1 (2C, ArC-2' and ArC-6'), 128.3 (C-2), 129.1 (2C, ArC-3"' and ArC-5"'), 136.8 (ArC-1"'), 137.6 (ArC-4"'), 140.4 (ArC1'), $142.5(\mathrm{C}-3), 148.0(\mathrm{C}-8)$ and $174.6(\mathrm{C}=\mathrm{O})$.

(1S,2"R,5S)- and (1S,2"S,5S)-2-(4-Isobutylphenyl)propionic acid 5-isopropenyl-2-methyl-3-p-tolylcyclohex2-enyl ester 27a,b: Oil. Yield $=26 \%$. $[\alpha]_{\mathrm{D}}{ }^{25}+101.5$ (c 2.66, $\mathrm{CHCl}_{3}$ ). IR (film, $v_{\max } / \mathrm{cm}^{-1}$ ): 2924, 1730, 1512, 1452, 1375, 1315, 1199, 1165, 956, 891 and 818. Major diastereomer, $(1 S, 2$ " $S, 5 S)$-27: ${ }^{1} \mathrm{H}$ NMR: $\delta 0.85(\mathrm{~d}, 6 \mathrm{H}, J$ 6.2, $\left.\mathrm{ArCH}_{2} \mathrm{CHMe} e_{2}\right), 1.16$ (s, 3H, H-3"), 1.49-1.63 (m, 4H, $\mathrm{H}-6_{\text {ax }}$ and $\mathrm{H}-7$ ), 1.72 (s, 3H, H-10), 1.81 (tq, $1 \mathrm{H}, J 6.8$ and $6.8, \mathrm{H}-8$ "'), $2.07-2.37$ (m, 6H, H-4 ${ }_{\mathrm{ax}}, \mathrm{H}-4_{\mathrm{eq}}, \mathrm{H}-6_{\mathrm{eq}}$ and H-7'), 2.37-2.50 (m, 3H, H-5 and H-7"'), 3.72 (q, $1 \mathrm{H}, J 7.1, \mathrm{H}-2$ "), 4.73 (m, $2 \mathrm{H}, \mathrm{H}-9$ and $\mathrm{H}-9$ ) $), 5.52$ (bs, $1 \mathrm{H}, \mathrm{H}-1), 6.96-7.17$ (m, 6H, ArH) and 7.19-7.26 (m, 2H, ArH). ${ }^{13} \mathrm{C}$ NMR: $\delta 15.2$
(C-7), 18.1 (ArCHMe), 20.4 (C-10), 21.0 ( $\mathrm{Ph} M e$ ), 22.2 (2C, C-9"'), 30.1 ( $\mathrm{ArCH}_{2} \mathrm{CHMe}_{2}$ ), 33.8 (C-6), 37.4 (C-4), 39.8 (C-5), $44.9\left(\mathrm{ArCH}_{2} \mathrm{CHMe}_{2}\right), 45.4$ (C-2"), 74.5 (C-1), 109.3 (C-9), 127.9 (2C, ArC-2' and ArC-6'), 128.0 (2C, ArC-2"' and ArC-6"'), 128.6 (2C, ArC-3"' and ArC-5"'), 129.1 (2C, ArC-3' and ArC-5'), 136.0, 136.4, 137.6, 137.8, 139.5 and 140.3 (6C, C-2, C-3, C-1', C-4', C-1"' and C-4"'), 148.0 (C$8)$ and $174.4(\mathrm{C}=\mathrm{O})$. Minor diastereomer, $(1 S, 2 " R, 5 S)-27$ : ${ }^{1} \mathrm{H}$ NMR: $\delta 0.88$ (d, 6H, $J$ 6.7, $\left.\mathrm{ArCH}_{2} \mathrm{CHMe} e_{2}\right), 1.44$ (s, $3 \mathrm{H}, \mathrm{H}-3$ "), 1.49-1.63 (m, 4H, H-6 ax and H-7), 1.68 (s, 3H, $\mathrm{H}-10$ ), 1.84 (tq, $1 \mathrm{H}, J 6.8$ and 6.8, H-8"'), 2.38-2.50 (m, $6 \mathrm{H}, \mathrm{H}-4_{\mathrm{ax}}, \mathrm{H}-4_{\mathrm{eq}}, \mathrm{H}-6_{\mathrm{eq}}$ and H-7'), 2.38-2.51 (m, 3H, H-5 and H-7"'), 3.73 (q, 1H, J 7.1, H-2"), 4.68 (m, 1H, H-9), 4.70 (m, 1H, H-9 ) 5.53 (bs, 1H, H-1), 6.96-7.17 (m, 6H, $\mathrm{ArH})$ and 7.19-7.27 (m, 2H, ArH). ${ }^{13} \mathrm{C}$ NMR: $\delta 15.6(\mathrm{C}-$ 7), 18.4 ( $\mathrm{ArCHMe}$ ), 20.4 (C-10), 21.0 ( $\mathrm{PhMe}), 22.2$ (2C, C-9"'), 30.1 ( $\mathrm{ArCH}_{2} \mathrm{CHMe}_{2}$ ), 33.4 (C-6), 37.4 (C-4), 39.9 (C-5), $44.9\left(\mathrm{ArCH}_{2} \mathrm{CHMe}_{2}\right), 45.4$ (C-3), 74.4 (C-1), 109.3 (C-9), 127.1 (2C, ArC-2' and ArC-6'), 128.1 (2C, ArC-2"' and ArC-6"'), 128.7 (2C, ArC-3"' and ArC-5"'), 129.1 (2C, ArC-3' and ArC-5'), 136.0, 136.4, 137.6, 137.8, 139.5 and 140.3 (6C, C-2, C-3, C-1', C-4', C-1"' and C-4"'), 148.0 $(\mathrm{C}-8)$ and $174.6(\mathrm{C}=\mathrm{O})$.

(1S,2" R,5S)- and (1S,2"S,5S)-2-(4-Isobutylphenyl)propionic acid 5-isopropenyl-2-methyl-3-(4methoxyphenyl)-cyclohex-2-enyl ester 28a,b: Oil. Yield = 90\%. $[\alpha]_{\mathrm{D}}^{25}+114.4\left(c \mathrm{1} 1.21, \mathrm{CHCl}_{3}\right)$. IR (film, $v_{\max } / \mathrm{cm}^{-1}$ ): 3057, 2932, 1731, 1646, 1581, 1484, 1449, 1419, 1180, $1088,893,801$ and 780. Major diastereomer, (1S,2"S,5S)-28: ${ }^{1} \mathrm{H}$ NMR: $\delta 0.85$ (d, 6H, J 6.2, H-9"'), 1.16 (s, 3H, H-7), 1.52 (d, 3H, J 7.2, H-3"), 1.52-1.64 (m, 1H, H-6 ${ }_{a x}$ ), 1,73 (s, $3 \mathrm{H}, \mathrm{H}-10), 1.74-1.90$ (m, 1H, H-8"'), 2.07-2.34 (m, 3H, $\mathrm{H}-4_{\text {eq }}, \mathrm{H}-4_{\text {ax }}$ y H-6 $\left.{ }_{\text {eq }}\right), 2.34-2.49$ (m, 3H, H-5 and H-7"'), 3.72 (q, 1H, J 7.2, H-2"), 3.79 (s, 3H, OMe), 4.73 (m, 2H, H-9 and H-9 $)$, 5.47-5.61 (m, 1H, H-1), 6.80-6.91 (m, 2H, ArH-3' and ArH-5'), 6.99-7.13 (m, 4H, ArH-2', ArH-6', ArH-3"' and ArH-5"') and 7.19-7.28 (m, 2H, ArH-2"' and ArH-6"'). ${ }^{13}$ C NMR: $\delta 15.3$ (C-7), 18.1 (C-3"), 20.4 (C-10), 22.2 (2C, C-9"'), 30.2 (C-8"'), 33.8 (C-6), 37.5 (C-4), 39.8 (C-5), 44.9 (C-7"'), 45.4 (C-2”), 55.1 (OMe), 74.5 (C-1), 109.3 (C-9), 113.3 (2C, ArC-3' and ArC-5'), 127.1 (2C, ArC-2"' and ArC-6"'), 128.1 (C-2), 129.1 (2C, ArC-2' and ArC-6'), 129.2 (2C, ArC-3"' and ArC-5"'), 134.7 (ArC-1'), 136.0 (ArC-1"'), 137.8 (C-3), 140.3 (ArC-4"'), 148.0 (C8), 158.1 (ArC-4') and 174.4 (C=O). Minor diastereomer, $(1 S, 2 " R, 5 S)-28:{ }^{1} \mathrm{H}$ NMR: $\delta 0.88$ (d, 6H, $J$ 6.7, H-9"'), 1.36-1.49 (m, 4H, H-6 ax and H-7), 1.53 (d, 3H, J 7.2, H-3"), 1.68 (s, 3H, H-10), 1.74-1.93 (m, 1H, H-8"'), 2.07-2.50 (m, $6 \mathrm{H}, \mathrm{H}-4_{\mathrm{eq}}, \mathrm{H}-4_{\mathrm{ax}}, \mathrm{H}-5, \mathrm{H}-6_{\mathrm{eq}}$ and H-7'”), 3.75 (q, 1H, J 7.2, H-2"), 3.80 (s, 3H, OMe), 4.68 (s, 1H, H-9 b $^{2}, 4.71$ (s, 1H, 
H-9 ) , 5.47-5.61 (m, 1H, H-1), 6.80-6.91 (m, 2H, ArH-3' and ArH-5'), 6.99-7.13 (m, 4H, ArH-2', ArH-6', ArH-3"', and ArH-5"') and 7.19-7.28 (m, 2H, ArH-2"' and ArH-6"'). ${ }^{13}$ C NMR: $\delta 15.6$ (C-7), 18.4 (C-3"), 20.4 (C-10), 22.2 (2C, C-9"'), 30.1 (C-8"'), 33.4 (C-6), 37.5 (C-4), 39.8 (C-5), 44.9 (C-7”"), 45.4 (C-2"), 55.1 (OMe), 74.5 (C-1), 109.3 (C-9), 113.4 (2C, ArC-3' and ArC-5'), 127.1 (2C, ArC-2'" and ArC-6"'), 127.8 (C-2), 129.1 (2C, ArC-2' and ArC-6'), 129.2 (2C, ArC-3"' and ArC-5"'), 134.8 (ArC-1'), 136.3 (ArC-1"'), 137.6 (C-3), 140.3 (ArC-4"'), 148.0 (C-8), 158.1 (ArC-4') and 174.6 (C=O).

$(1 R, 2 S, 2 " R, 3 R, 5 R)-$ and $(1 R, 2 S, 2 " S, 3 R, 5 R)-2-(4-$ Isobutylphenyl)-propionic acid 5-isopropenyl-2-methyl3-phenylcyclohexyl ester 29a,b: Oil. Yield $=96 \%$. $[\alpha]_{\mathrm{D}}{ }^{25}-28.6\left(c 1.42, \mathrm{CHCl}_{3}\right)$. IR (film, $\left.v_{\max } / \mathrm{cm}^{-1}\right)$ : 2957, $1729,1602,1514,1454,1382,1213,1204,1069,757$ and 701. Major diastereomer, $(1 R, 2 S, 2 " R, 3 R, 5 R)-29$ : ${ }^{1} \mathrm{H}$ NMR: $\delta 0.44$ (d, 3H, $J$ 6.9, H-7), 0.88 (s, 3H, $J$ 6.6, $\mathrm{ArCH}_{2} \mathrm{CHMe}$ ), 0.90 (d, 3H, J 6.6, $\mathrm{ArCH}_{2} \mathrm{CHMe}$ ), 1.53 (d, 3H, J 7.1, ArCHMe), 1.75 (s, 3H, H-10), 1.89 (septet, J 6.6, $\mathrm{ArCH}_{2} \mathrm{CHMe}_{2}$ ), 1.80-1.93 (m, 2H, H-5, H-6), 2.00-2.20 (m, 2H, H-2 and H-4), 2.30 (bdt, 1H, J 4.6 and 10.6, H-6), 2.41 (d, 2H, J 7.2, $\mathrm{ArCH}_{2} \mathrm{CHMe}_{2}$ ), 2.87 (dt, 1H, J 4.0 and 8.1, H-3), 3.67 (q, 1H, J 7.1, ArCHMe), 4.84 (s, 1H, H-9), 4.86 (s, 1H, H-9), 5.09 (dt, 1H, J 3.4 and 6.9, H-1), 7.18 (d, 2H, $J$ 8.1, H-3"' and H-5"'), 7.20-7.33 (m, 5H, ArH) and 7.24 (d, 2H, $J$ 8.1, H-2"' and H-6"'). ${ }^{13} \mathrm{C}$ NMR: $\delta 14.6$ (C-7), 17.6 ( $\mathrm{ArCHMe}$ ), 22.3 (C-10), 22.3 (2C, $\mathrm{ArCH}_{2} \mathrm{CHMe} e_{2}$ ), $30.2\left(\mathrm{ArCH}_{2} \mathrm{CHMe}_{2}\right), 31.4(\mathrm{C}-6)$, ** $33.8(\mathrm{C}-4)$, ** $37.6(\mathrm{C}-$ 3), 38.0 (C-5), 42.1 (C-2), $45.0\left(\mathrm{ArCH}_{2}\right), 45.3$ ( $\left.\mathrm{ArCHMe}\right)$, 73.5 (C-1), 108.8 (C-9), 125.9 (C-4'), 127.3 (2C, C-2' and C-6'), 127.4 (2C, C-2"' and C-6"'), 128.4 (2C, C-3' and C-5'), 129.2 (C-3"' and C-5"'), 138.0 (C-1"'), 140.4 (C4"'), $144.7(\mathrm{C}-1$ '), $148.2(\mathrm{C}-8)$ and $174.3(\mathrm{C}=\mathrm{O})$. Minor diastereomer, $(1 R, 2 S, 2$ " $S, 3 R, 5 R)$-29: ${ }^{~} \mathrm{H}$ NMR: $\delta 0.69(\mathrm{~d}$, $3 \mathrm{H}, J$ 6.9, H-7), 0.88 (s, 3H, J 6.6, $\mathrm{ArCH}_{2} \mathrm{CHMe}$ ), 0.90 (d, $3 \mathrm{H}, J$ 6.6, $\left.\mathrm{ArCH}_{2} \mathrm{CHMe} e_{2}\right), 1.54$ (d, 3H, J 7.1, АrCHMe), 1.75 (s, 3H, H-10), 1.89 (septet, $J$ 6.6, $\mathrm{ArCH}_{2} \mathrm{CHMe}_{2}$ ), 1.80-1.93 (m, 2H, H-5, H-6), 2.00-2.20 (m, 2H, H-2 and H-4), 2.30 (bdt, $1 \mathrm{H}, J 4.6$ and 10.6, H-6), 2.41 (d, 2H, $J$ 7.2, $\mathrm{ArCH}_{2} \mathrm{CHMe}_{2}$ ), 2.93 (dt, $1 \mathrm{H}, J 4.0$ and 8.1, H-3), 3.69 (q, 1H, J 7.1, ArCHMe), 4.80 (s, 1H, H-9), 4.82 (s, 1H, H-9), 5.10 (dt, 1H, J 3.4 and 6.9, H-1), 7.18 (d, 2H, J 8.1, H-3"' and H-5"'), 7.20-7.33 (m, 5H, ArH) and 7.24 (d, $2 \mathrm{H}, J$ 8.1, H-2"' and H-6"'). ${ }^{13} \mathrm{C}$ NMR: $\delta 14.9$ (C-7), 17.8 (ArCHMe), 22.0 (C-10), 22.3 (2C, $\left.\mathrm{ArCH}_{2} \mathrm{CHMe}{ }_{2}\right), 30.2$ $\left(\mathrm{ArCH}_{2} \mathrm{CHMe}_{2}\right), 31.3$ (C-6), ** 33.7 (C-4), ** 37.6 (C-3), 38.0 (C-5), 42.1 (C-2), $45.0\left(\mathrm{ArCH}_{2}\right), 45.8$ (ArCHMe), 73.6 (C-1), 108.8 (C-9), 125.9 (C-4'), 127.3 (2C, C-2' and C-6'), 127.4 (2C, C-2"' and C-6"'), 128.4 (2C, C-3' and
C-5'), 129.2 (C-3"' and C-5"'), 138.0 (C-1"'), 140.4 (C4"'), 144.7 (C-1'), $148.2(\mathrm{C}-8)$ and $174.3(\mathrm{C}=\mathrm{O})$.

$(1 R, 2 S, 2$ " $R, 3 R, 5 R)-$ and $(1 R, 2 S, 2$ " $S, 3 R, 5 R)-2-(4-$ Isobutylphenyl)-propionic acid 5-isopropenyl-2-methyl-3naphthalen-1-yl-cyclohexyl ester 30a,b: Oil. Yield $=72 \%$. $[\alpha]_{\mathrm{D}}^{25}-16.3\left(c 1.00, \mathrm{CHCl}_{3}\right)$. IR (film, $\left.v_{\max } / \mathrm{cm}^{-1}\right): 3057$, 2932, 1731, 1646, 1581, 1484, 1449, 1419, 1180, 1088, 893, 801 and 780. Major diastereomer, $(1 R, 2 S, 2 " R, 3 R, 5 R)-30$ : ${ }^{1} \mathrm{H}$ NMR: $\delta 0.40$ (d, 3H, $J$ 6.9, H-7), 0.75 (d, 3H, $J$ 6.6, $\mathrm{ArCH}_{2} \mathrm{CHMe}$ ), 0.76 (d, 3H, J 6.6, $\mathrm{ArCH}_{2} \mathrm{CHMe}$ ), 1.55 (d, 3H, J 7.1, ArCHMe), 1.77 (s, 3H, H-10), 1.78 (septet, J 6.6, $\mathrm{ArCH}_{2} \mathrm{CHMe}$ ), 1.83-1.94 (m, 2H, H-5, H-6), 2.10-2.21 $(\mathrm{m}, 2 \mathrm{H}, \mathrm{H}-2$ and $\mathrm{H}-4), 2.30$ (ddt, $1 \mathrm{H}, J$ 1.6, 5.8 and 13.8, H-6), 2.39 (d, 2H, J 7.2, $\mathrm{ArCH}_{2} \mathrm{CHMe}_{2}$ ), 3.69 (q, 1H, J 7.1, $\mathrm{ArCHMe}$ ), 3.77 (dt, 1H, $J 4.5$ and 9.3, H-3), 4.88 (bd, $1 \mathrm{H}, J$ $1.5, \mathrm{H}-9), 4.91$ (s, 1H, H-9), 5.19 (dt, $1 \mathrm{H}, J 2.9$ and 5.8, H-1), 7.08 (d, 2H, J 8.1, H-3"' and H-5"'), 7.23 (d, 2H, J 8.1, H-2"' and H-6"'), 7.42-7.57 (m, 4H, H-2', H-3', H-6' and H-7'), 7.69 (dd, 1H, $J 3.1$ and, 6.2, H-4'), 7.85 (dd, $1 \mathrm{H}, J 1.6$ and 8.0, H-5') and 8.01 (bd, $\left.1 \mathrm{H}, J 8.0, \mathrm{H}-8^{\prime}\right) .{ }^{13} \mathrm{C} \mathrm{NMR:} \delta 14.7$ (C7), $17.6(\mathrm{ArCH} M e), 22.2(\mathrm{C}-10)$, ** $22.3\left(\mathrm{ArCH}_{2} \mathrm{CHMe} e_{2}\right)$,** $\left.22.4\left(\mathrm{ArCH}_{2} \mathrm{CHMe}\right)_{2}\right) * * 30.1\left(\mathrm{ArCH}_{2} \mathrm{CHMe}_{2}\right), 31.7$ (C6), ** 35.1 (C-4), ** 35.6 (C-3), 38.3 (C-5), 39.8 (C-2), 45.0 $\left(\mathrm{ArCH}_{2}\right), 45.4$ (ArCHMe), 74.1 (C-1), 108.7 (C-9), 123.2 (C-8'), ${ }^{*} 123.3$ (C-2'), ${ }^{\prime} 125.2$ (C-6'), ** $125.6\left(\mathrm{C}-3^{\prime}\right)$, ** 125.7 (C-7'), ** 126.4 (C-4'), 127.4 (2C, C-2"' and C-6"'), 129.0 (C-5'), 129.2 (C-3"' and C-5'"), 132.2 (C-8a'), 134.0 (C-4a'), 138.1 (C-1"'), 140.4 (C-4"'), 141.9 (C-1'), 148.2 (C-8) and $174.4(\mathrm{C}=\mathrm{O})$. Minor diastereomer, $(1 R, 2 S, 2$ " $S, 3 R, 5 R)-30$ : ${ }^{1} \mathrm{H}$ NMR: $\delta 0.67$ (d, 3H, J 6.9, H-7), 0.75 (d, 3H, J 6.6, $\mathrm{ArCH}_{2} \mathrm{CHMe}$ ), 0.76 (d, 3H, J 6.6, $\mathrm{ArCH}_{2} \mathrm{CHMe}$ ) 1.56 (d, 3H, J 7.1, ArCHMe), 1.77 (s, 3H, H-10), 1.78 (septet, J 6.6, $\mathrm{ArCH}_{2} \mathrm{CHMe}$ ), 1.83-1.94 (m, 2H, H-5, H-6), 2.10-2.21 $(\mathrm{m}, 2 \mathrm{H}, \mathrm{H}-2$ and $\mathrm{H}-4), 2.30$ (ddt, $1 \mathrm{H}, J$ 1.6, 5.8 and 13.8, H-6), 2.43 (d, 2H, J 7.2, $\mathrm{ArCH}_{2} \mathrm{CHMe}_{2}$ ), 3.69 (q, 1H, J 7.1, ArCHMe), 3.83 (dt, 1H, J 4.5 and9.3, H-3), 4.79 (bd, 1H, $J 1.5, \mathrm{H}-9$ ), 4.89 (s, $1 \mathrm{H}, \mathrm{H}-9), 5.22$ (dt, $1 \mathrm{H}, J 2.9$ and 5.8, H-1), 7.10 (d, 2H, $J$ 8.1, H-3"' and H-5"'), 7.25 (d, 2H, $J$ 8.1, H-2"' and H-6"'), 7.42-7.57 (m, 4H, H-2', H-3', H-6' and ${\left.\mathrm{H}-7^{\prime}\right)}^{\prime}, 7.70$ (dd, $1 \mathrm{H}, J 3.1$ and 6.2, $\left.\mathrm{H}-4^{\prime}\right), 7.87$ (dd, $1 \mathrm{H}, J$ 1.6 and 8.0, H-5') and 8.11 (bd, $1 \mathrm{H}, J$ 8.0, $\left.\mathrm{H}^{-} 8^{\prime}\right) .{ }^{13} \mathrm{C}$ NMR: $\delta$ 15.2 (C-7), 18.2 (ArCHMe), $22.3\left(\mathrm{ArCH}_{2} \mathrm{CHMe}\right)_{2}$, ** 22.4 $\left(\mathrm{ArCH}_{2} \mathrm{CHMe}\right)_{2}$, ** 22.7 (C-10), ** $30.1\left(\mathrm{ArCH}_{2} \mathrm{CHMe}_{2}\right)$, 31.9 (C-6), ** 34.7 (C-4), ** 36.1 (C-3), 38.3 (C-5), 39.4 (C2), $45.0\left(\mathrm{ArCH}_{2}\right), 45.8$ ( $\left.\mathrm{ArCHMe}\right), 74.3$ (C-1), 108.8 (C-9),

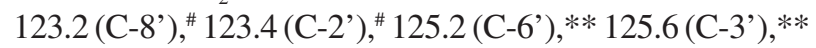
125.8 (C-7'),** 126.5 (C-4'), 127.4 (2C, C-2"' and C-6"'), 129.1 (C-5'), 129.2 (C-3"' and C-5"'), 132.2 (C-8a'), 134.1 (C-4a'), 138.1 (C-1"'), 140.4 (C-4"'),141.8 (C-1'), 148.2 (C-8) and $174.4(\mathrm{C}=\mathrm{O})$. 
(1S,2S,2"R,5R)- and (1S,2S,2”S,5R)-2-(4-Isobutylphenyl)-propionic acid 2-isopropyl-5-methyl-cyclohexyl ester 32: Oil. Yield $=97 \%$. IR (film, $\left.v_{\max } / \mathrm{cm}^{-1}\right)$ : 2930, 2121, 1730, 1513, 1451, 1360, 1258, 1241, 1203, 1170, 1094, 1048, 956, 891, 845 and 799. ${ }^{1} \mathrm{H}$ NMR: $\delta 0.49$ and $0.70(\mathrm{~d}, 3 \mathrm{H}, J 6.9, \mathrm{H}-9)$, ** 0.66 and 0.81 (s, 3H, $J 6.9$, $\mathrm{H}-10)$, ** 0.77-1.15 (m, 1H, H-6), 0.81 (d, 3H, J 6.9, H-7), 0.88 (d, 6H, J 6.6, $\mathrm{ArCH}_{2} \mathrm{CHMe}$ ), 1.18-1.40 (m, 3H, H-3, $\mathrm{H}-4), 1.46$ and 1.48 (d, 3H, $J$ 6.0, ArCHMe), 1.80-2.00 (m, 1H, H-6), 2.44 (d, 2H, J 7.4, $\mathrm{ArCH}_{2}$ ), 3.15-3.23 (m, $1 \mathrm{H}, \mathrm{H}-2), 3.63$ and 3.65 (q, $1 \mathrm{H}, J$ 7.5, ArCHMe), 4.60 and 4.61 (q, 1H, H-1), 7.06 and 7.07 (d, 2H, J 7.8, ArH-3' and ArH-5')** and 7.17 and 7.19 (d, 2H, J 7.8, ArH-2' and ArH-6').** ${ }^{13}$ C NMR: $\delta 15.9$ and $16.2(\mathrm{C}-9), * * 18.2$ and 18.3 (ArCHMe), 20.5 and 20.7 (C-10),** 21.9 and 22.0 $\left(\mathrm{ArCH}_{2} \mathrm{CHMe} e_{2}\right),{ }^{\#} 22.2$ and $22.3\left(\mathrm{ArCH}_{2} \mathrm{CHMe} e_{2}\right),{ }^{\#} 23.2$ and 23.4 (C-7), 24.5 and 25.5 (C-3), 26.1 (C-8), 30.1 and 30.2 $\left(\mathrm{ArCH}_{2} \mathrm{CHMe}_{2}\right), 31.3$ and 31.4 (C-5), 34.3 and 34.9 (C-4), 40.4 and 40.9 (ArCHMe), 45.0 and $45.4\left(\mathrm{ArCH}_{2}\right), 46.9$ and 47.1 (C-6), 55.7 (C-2), 74.2 and 74.3 (C-1), 127.0 and 127.1 (2C, C-2' and C-6'), ** 129.1 (2C, C-3' and C-5'), ** 137.9 and $138.2\left(\mathrm{C}-1^{\prime}\right), 140.3(\mathrm{C}-4$ ') and 174.2 and $174.3(\mathrm{C}=\mathrm{O})$.

(3R,6S)-2-(4-Bromobenzylidene)-6-isopropyl-3methyl-cyclohexanone 34: A solution of (-)-menthone (33, $260 \mathrm{mg}, 1.68 \mathrm{mmol})$ and 4-bromobenzaldehyde (312 $\mathrm{mg}, 1.68 \mathrm{mmol})$ in DMSO $(10 \mathrm{~mL})$, was treated with $\mathrm{K}^{t} \mathrm{BuO}$ (20 mg, $\left.0.17 \mathrm{mmol}\right)$. After stirring $12 \mathrm{~h}$ at room temperature, saturated $\mathrm{NH}_{4} \mathrm{Cl}(15 \mathrm{~mL})$ and water $(15 \mathrm{~mL})$ were added and the organic product was extracted with EtOAc $(4 \times 50 \mathrm{~mL})$. The combined organic extracts were washed with brine $(10 \mathrm{~mL})$, dried over $\mathrm{Na}_{2} \mathrm{SO}_{4}$, concentrated under reduced pressure and the residue was chromatographed, furnishing 34 (145.2 mg, 43\%) as a white solid, mp 100-102 ${ }^{\circ} \mathrm{C}$ (hexane-EtOAc). $[\alpha]_{\mathrm{D}}^{25}-53.3$ (c 1.33, $\left.\mathrm{CHCl}_{3}\right)$. IR $\left(\mathrm{KBr}, v_{\text {max }} / \mathrm{cm}^{-1}\right): 2954,2931,1674,1608,1438$, 1398, 1170, 1095, 1068, 1004, 835 and 756. ${ }^{1} \mathrm{H}$ NMR: $\delta$ 0.89 (d, 3H, J 7.1, H-9), 0.96 (d, 3H, J 7.1, H-10), 1.16 (d, $3 \mathrm{H}$, J 7.1, H-7), 1.75-1.82 (m, 1H, H-4), 1.82-1.90 (m, 3H, H-4 and H-5), 2.22 (ddd, 1H, J 3.6, 8.6 and 10.0, H-6), 2.54 (d-septet, 1H, J 3.3 and 6.8, H-8), 3.28-3.38 (bs, 1H, H-3), $7.01(\mathrm{~s}, 1 \mathrm{H},=\mathrm{C}-H), 7.20$ (d, 2H, $J$ 8.1, H-3' and H-5') and 7.49 (d, 2H, $J$ 8.1, H-2' and H-6'). ${ }^{13} \mathrm{C}$ NMR: $\delta 17.8$ (C-9), 18.7 (C-5), 19.7 (C-7), 20.4 (C-10), 26.6 (C-8), 30.5 (C-4), 31.7 (C-3), 56.0 (C-6), 122.2 (C-4'), 131.0 (3C, C-2', C-6' and $\mathrm{ArCH}-\mathrm{C}), 131.6$ (2C, C-3' and C-5'), 134.8 (C-1'), $145.5(\mathrm{C}-2)$ and $204.7(\mathrm{C}=\mathrm{O})$.

(1S,3R,6S)-2-(4'-Bromobenzylidene)-6-isopropyl3-methyl-cyclohexanol 35: $\mathrm{NaBH}_{4}(20 \mathrm{mg}, 0.52 \mathrm{mmol})$ was added to a stirred solution of ketone 34 (42 mg,
$0.13 \mathrm{mmol})$ in THF-MeOH $(2: 1,2 \mathrm{~mL})$ kept at $0{ }^{\circ} \mathrm{C}$. After $30 \mathrm{~min}$, acetone $(0.5 \mathrm{~mL})$ was added and 5 min later the organic solvent was removed under reduced pressure and the residue was chromatographed, furnishing $\mathbf{3 5}$ (28 mg, $66 \%$ ) as a white solid $\mathrm{mp} 128-130{ }^{\circ} \mathrm{C}$ (hexane-EtOAc). $[\alpha]_{\mathrm{D}}^{25}-70.3\left(c 1.05, \mathrm{CHCl}_{3}\right)$. IR $\left(\mathrm{KBr}, v_{\max } / \mathrm{cm}^{-1}\right): 2453$, 2951, 2897, 1650, 1484, 1383, 1077, 1009, 977, 867, 760, 717 and 633. ${ }^{1} \mathrm{H}$ NMR: $\delta 0.92$ (d, 3H, J 7.0, H-9), ${ }^{* *} 0.96$ (d, 3H, J 7.0, H-10), ** 1.13 (d, 3H, J 7.3, H-7), 1.31 (m, 1.27-1.36, 1H, H-6), 1.44-1.56 (m, 4H, H-4 and H-5), 2.25 (d-septet, $1 \mathrm{H}, J 2.9$ and 7.0, H-8), 3.10-3.18 (m, 1H, H-3), 4.26 (dd, 1H, J 1.2 and 13.5, H-1), 6.52 (d, 1H, J 1.8, $\mathrm{ArCH}=), 7.05$ (d, 2H, J 8.4, H-2' and H-6') and 7.42 (d, $2 \mathrm{H}, J$ 8.4, H-3' and H-5'). ${ }^{13} \mathrm{C}$ NMR: $\delta 15.9$ (C-9), ** 18.4 (C-5), 18.8 (C-10), ** 20.8 (C-7), 26.7 (C-8), 31.2 (C-3), 32.3 (C-4), 52.6 (C-6), 70.3 (C-1), $117.3(\mathrm{ArCH}=), 119.8$ (C-4'), 130.3 (2C, C-2' and C-6'), 130.9 (2C, C-3' and C-5'), 137.7 (C-1') and 150.0 (C-2).

( $1 S, 2$ " $R, 3 R, 6 S)$ - and (1S,2 " S, 3R, 6S)-2-(4Isobutylphenyl)-propionic acid 2-(4-bromobenzylidene)6-isopropyl-3- methyl-cyclohexyl ester 36a,b: DMAP ( $8.6 \mathrm{mg}, 0.07 \mathrm{mmol}$ ) and ibuprofen $(18.2 \mathrm{mg}, 0.07 \mathrm{mmol})$ were successively added to a stirred solution of alcohol 35 (22.7 mg, $0.07 \mathrm{mmol})$ in $\mathrm{CHCl}_{3}(3 \mathrm{~mL})$. The mixture was treated with a solution of DCC $(18.2 \mathrm{mg}, 0.07 \mathrm{mmol})$ in $\mathrm{CHCl}_{3}(0.5 \mathrm{~mL})$. After stirring overnight at room temperature, the organic solvent was removed under reduced pressure and the residue was chromatographed, furnishing 36 as an oil (34.9 mg, 97\%). $[\alpha]_{\mathrm{D}}^{25}-40.4(c$ 1.60, $\mathrm{CHCl}_{3}$ ). IR (film, $\left.v_{\max } / \mathrm{cm}^{-1}\right): 2957,1742,1486,1164$, 1010,852 and 812. Major diastereomer, $(1 S, 2 " R, 3 R, 6 S)-36$ : ${ }^{1} \mathrm{H}$ NMR: $\delta 0.60$ (d, 3H, J 6.9, H-9), ** 0.70 (d, 3H, J 6.9, $\mathrm{H}-10)$, $* * 0.88$ (d, 6H, J 6.6, $\left.\mathrm{ArCH}_{2} \mathrm{CHMe} e_{2}\right), 1.17$ (d, 3H, $J$ 7.2, H-7), 1.30-1.55 (m, 6H, H-4, H-5, H-6 and H-8), 1.55 (d, 3H, J 7.1, ArCHMe), 1.80 (septet, 1H, J 6.9, $\mathrm{ArCH}_{2} \mathrm{CHMe}_{2}$ ), 2.44 (d, 2H, J 7.1, $\mathrm{ArCH}_{2} \mathrm{CHMe}_{2}$ ), 3.043.14 (m, 1H, H-3), 3.81 (q, 1H, J 7.1, ArCHMe), 5.41 (bd, $J$ 8.4, 1H, H-1), 5.95 (s, 1H, ArCH=C), 6.97 (d, 2H, J 8.0, H-3' and H-5'), 7.08 (d, 2H, J 8.3, H-3" and H-5"), 7.25 (d, 2H, J 8.3, H-2" and H-5") and 7.40 (d, 2H, J 8.0, H-2' and $\mathrm{H}-6$ '). ${ }^{13} \mathrm{C}$ NMR: $\delta 15.5$ (C-9), ${ }^{* *} 17.8$ (ArCHMe), 18.3 (C-7), 18.4 (C-5), 20.5 (C-10), ** 22.3 (2C, $\mathrm{ArCH}_{2} \mathrm{CHMe}{ }_{2}$, 26.2 (C-8), $30.1\left(\mathrm{ArCH}_{2} \mathrm{CHMe}_{2}\right), 31.4$ (C-3), 32.2 (C-4), 45.0 (ArCHMe), $45.5\left(\mathrm{ArCH}_{2} \mathrm{CHMe}_{2}\right), 50.1$ (C-6), 72.4 (C-1), 117.2 ( $\mathrm{ArCH}=\mathrm{C}), 119.8$ (C-4'), 127.3 (2C, C-2" and C-6"), 129.3 (2C, C-3" and C-5"), 130.5 (2C, C-2' and C-6'), 131.1 (2C, C-3' and C-5'), 136.8 (C-1'), 137.6 (C-1"), 140.7 (C-4"), $145.5(\mathrm{C}-2)$ and $173.7(\mathrm{C}=\mathrm{O})$. Minor diastereomer, $(1 S, 2$ " $S, 3 R, 6 S)-36$ : ${ }^{~} \mathrm{H}$ NMR: $\delta 0.60(\mathrm{~d}, 3 \mathrm{H}$, $J$ 6.9, H-9), 0.70 (d, 3H, J 6.9, H-10), 0.84 (d, 6H, J 6.6, 
$\mathrm{ArCH}_{2} \mathrm{CHMe}$ ), 1.14 (d, 3H, J 7.2, H-7), 1.30-1.55 (m, 6H, H-4, H-5, H-6 and H-8), 1.54 (d, 3H, J 7.1, ArCHMe), 1.82 (septet, $1 \mathrm{H}, J 6.9, \mathrm{ArCH}_{2} \mathrm{CHMe}_{2}$ ), 2.39 (d, 2H, J 7.1, $\mathrm{ArCH}_{2} \mathrm{CHMe}_{2}$ ), 3.04-3.14 (m, 1H, H-3), 3.81 (q, 1H, $J$ 7.1, ArCHMe), 5.44-5.46 (m, 1H, H-1), $6.30(\mathrm{~s}, 1 \mathrm{H}$, $\mathrm{ArCH}=\mathrm{C}), 6.76$ (d, 2H, J 8.0, H-3' and H-5'), 7.05 (d, $2 \mathrm{H}, J$ 8.3, H-3" and H-5"), 7.25 (d, 2H, J 8.3, H-2" and H-5") and 7.32 (d, 2H, $J$ 8.0, H-2' and H-6'). ${ }^{13} \mathrm{C}$ NMR: $\delta 16.0$ (C-9), ** 18.1 (ArCHMe), 18.3 (C-7), 18.7 (C-5), 20.7 (C-10), ** $22.3\left(2 \mathrm{C}, \mathrm{ArCH}_{2} \mathrm{CHMe}\right.$ ), 26.9 (C-8), 30.2 ( $\mathrm{ArCH}_{2} \mathrm{CHMe}_{2}$ ), 31.3 (C-3), 32.2 (C-4), 45.0 (ArCHMe), $45.3\left(\mathrm{ArCH}_{2} \mathrm{CHMe}_{2}\right), 49.9$ (C-6), 72.1 (C-1), 117.3 ( $\mathrm{ArCH}=\mathrm{C}), 119.8$ (C-4'), 127.4 (2C, C-2" and C-6"), 129.4 (2C, C-3" and C-5"), 130.3 (2C, C-2' and C-6'), 131.0 (2C, C-3' and C-5'), 136.7 (C-1'), 137.7 (C-1"), 140.7 (C-4"), $145.0(\mathrm{C}-2)$ and $173.7(\mathrm{C}=\mathrm{O})$.

\section{Acknowledgements}

The authors are thankful to CONICET, ANPCyT, SECyT-UNR and Fundación Josefina Prats for their generous financial assistance. M. A. thanks ANPCyT and CONICET for her fellowships.

\section{References}

1. Reddy, I. K.; Mehva, R.; Chirality in Drug Design and Development. Marcel Dekker: New York, 2004; Francotte, E.; Linder, W.; Chirality in Drug Research. Wiley-VCH: Weinheim, 2006.

2. Kaehler, S. T.; Phleps, W.; Hesse, E.; Inflammopharmacology 2003, 11, 371 .

3. Knadler, M. P.; Hall, S. D.; Chirality 1990, 2, 67; Tracy, T. S.; Wirthwein, D. P.; Hall, S. D.; Drug Metab. Dispos. 1993, 21, 114; Hall, S. D.; Xiaotao, Q.; Chem.-Biol. Interact. 1994, 90, 235; Sanins, S. M.; Adams, W. J.; Kaiser, D. G.; Halstead, G. W.; Baillie, T. A.; Drug Metab. Dispos. 1990, 18, 527.

4. Li, C.; Benet, L. Z.; Grillo, M. P.; Chem. Res. Toxicol. 2002, 15, 1480; Grillo, M. P.; Hua, F.; Chem. Res. Toxicol. 2008, 21, 1749.

5. Rainsford, K. D.; Ibuprofen. A Critical Bibliographic Review. Taylor and Francis: London, 1999; Hutt, A. J.; Caldwell, J.; J. Pharm. Pharmacol. 1983, 35, 693; Bertola, M. A.; U.S. Pat. 5,108,917, 1992; Williams, K.; Day, R.; Kinhinicki, R.; Duffield, A.; Biochem. Pharmacol. 1986, 35, 3403.

6. Polet, D.; Alexakis, A.; Tetrahedron Lett. 2005, 46, 1529; Acemoglu, L.; Williams, J. M. J.; J. Mol. Catal. A: Chem. 2003, 196, 3; Sonawane, H. R.; Bellur, N. S.; Kulkarni, D. G.; Ayyangar, N. R.; Tetrahedron 1994, 50, 1243; Hamon, D. P. G.; Massy-Westropp, R. A.; Newton, J. L.; Tetrahedron: Asymmetry 1993, 4, 1435; Sonawane, H. R.; Nanjundiah, B. S.;
Kulkarni, D. G.; Ahuja, J. R.; Tetrahedron: Asymmetry 1991, 2 , 251; Oppolzer, W.; Rosset, S.; De Brabander, J.; Tetrahedron Lett. 1997, 38, 1539; Ishibashi, H.; Maeki, M.; Yagi, J.; Ohba, M.; Kanal, T.; Tetrahedron 1999, 55, 6075; Beaulieu, C.; Spino, C.; Tetrahedron Lett. 1999, 40, 1637; Jung, M. E.; Anderson, K. L.; Tetrahedron Lett. 1997, 38, 2605; Jang, E. J.; Lee, K. H.; Lee, J. S.; Kim, Y. G.; J. Molec. Catal. A: Chem. 1999, 138, 25; For a review on arylpropionic acids, see Sonawane, H.; Bellur, N. S.; Ahuja, J. R.; Kulkarni, D. G.; Tetrahedron: Asymmetry 1992, 3, 163 .

7. Lam, W. H.; Ng, K. M.; AIChE J. 2007, 53, 429; Bhattacharya, A.; Org. Process Res. Dev. 2003, 7, 717.

8. da Silva, V. C. F.; Contesini, F. J.; Carvalho, P. D.; J. Braz. Chem. Soc. 2008, 19, 1468; Henke, E.; Schuster, S.; Yang, H.; Bornscheuer, U. T.; Monatsh. Chem. 2000, 131, 633.

9. Kumar, I.; Manju, K.; Jolly, R.; Tetrahedron: Asymmetry 2001, 12, 1431; Cauwenberg, V.; Vergossen, P.; Stankiewicz, A.; Kierkels, H.; Chem. Eng. Sci. 1999, 54, 1473; Senanayake, C. H.; Bill, T. J.; Larsen, R. D.; Leazer, J.; Reider, P. J.; Tetrahedron Lett. 1992, 33, 5901.

10. Hirrilinger, B.; Andreas, S.; Kanckmuss, H. J.; J. Bacteriol. 1996, 178, 3501; Yamamoto, K.; Kazumasa, O.; Akira, M.; Takahiko, H.; Isao, F.; Ken-Ichi, K.; Appl. Environ. Microbiol. 1996, 62, 152; Effenberger, F.; Graef, B. W.; Osswald, S.; Tetrahedron: Asymmetry 1997, 8, 2749.

11. Cohen, M. A.; Parrat, J. S.; Turner, N. J.; Tetrahedron: Asymmetry 1992, 3, 1543; Kakeya, H.; Sakai, N.; Sugai, T.; Ohta, H.; Tetrahedron Lett. 1991, 32, 1343; Yamamoto, K.; Ueno, Y.; Otsubo, K.; Kawakami, K.; Komatsu, K.; Appl. Environ. Microbiol. 1990, 56, 3125.

12. Bando, T. ; Namba, Y. ; Shishido, K.; Tetrahedron: Asymmetry 1997, 8, 2159.

13. Tanaka, J.-I.; Oda, S.; Ohta, H.; J. Biosci. Bioeng. 2001, 91, 314.

14. Srikrishna, A.; Nagaraju, S.; Jagadeeshwar Reddy, T.; Venkateswarlu, S.; Pure Appl. Chem. 1996, 68, 699; Ho, T.L.; Enantioselective Synthesis: Natural Products from Chiral Terpens. Wiley: Chichester, 1992; Abad, A.; Agullo, C.; Castelblanque, L.; Cunar, A. C.; Navarro, I.; de Arellano, M. C. R.; J. Org. Chem. 2000, 65, 4189.

15. Corey, E. J.; Gin, D.; Kania, R. S.; J. Am. Chem. Soc. 1996, 118, 9202; Grygorenko, O. O.; Kopylova, N. A.; Mikhailiuk, P. K.; Meissner, A.; Komarov, I. V.; Tetrahedron: Asymmetry 2007, 18, 290; Rossi, J. C.; Marull, M.; Boiteau, L.; Taillades, J.; Eur. J. Org. Chem. 2007, 662.

16. For reviews, see: Pellisier, H.; Tetrahedron 2003, 59, 8291; Ward, R. S.; Tetrahedron: Asymmetry 1995, 6, 1475; Pellisier, H.; Tetrahedron 2008, 64, 1563.

17. Ammazzalorso, A.; Amoroso, R.; Bettonia, G.; De Filippis, B.; Giampietro, L.; Pierini, M.; Tricca, M. L.; Tetrahedron Lett. 2002, 43, 4325. 
18. Ammazzalorso, A.; Amoroso, R.; Bettoni, G.; De Filippis, B.; Fantacuzzi, M.; Giampietro, L.; Maccallini, C.; Tricca, M. L.; Eur. J. Org. Chem. 2006, 4088.

19. Neises, B.; Steglich, W.; Angew. Chem., Int. Ed. 1978, 17, 522; Wiener, H.; Gilon, C.; J. Mol. Catal. 1986, 37, 45.

20. Hargreaves, M. K.; Rabari, L. F.; Monatsh. Chem. 1983, 114, 195

21. Rodrigues de Almeida, Q. A.; de Oliveira Pereira, M. L.; Bezerra Coelho, R.; Martins de Carvalho, E.; Kaiser, C. R.; Jones Jr.; J.; Martins da Silva, F.; J. Braz. Chem. Soc. 2008, 19, 894.

22. Smitt, O.; Hoegberg, H. E.; J. Chem. Res. (S) 2002, 11, 527; Bakuzis, P.; Bakuzis, M. L. F.; J. Org. Chem. 1981, 46, 235.

23. Cohen, T.; Yu, L.-C.; J. Org. Chem. 1985, 50, 3266.

24. Nicolaou, K. C.; Groneberg, R. D.; J. Am. Chem. Soc. 1990, 112, 4085.

25. Miyashita, M.; Suzuki, T.; Yoshikoshi, A.; J. Org. Chem. 1985, 50, 3377.

26. García-Gutiérrez, J. L.; Fuentes, G. A.; Hernández-Terán, M. E.; García, P.; Murrieta-Guevara, F.; Jiménez-Cruz, F.; Appl. Catal., A 2008, 334, 366.

27. Srikrishna, A.; Chikkana, D.; Tetrahedron: Asymmetry 2005, 16, 2203.
28. Mehta, G.; Umarye, J. D.; Gagliardini, V.; Tetrahedron Lett. 2002, 43, 6975; Srikrishna, A.; Dethe, D. H.; Org. Lett. 2004, 6, 165; Mehta, G.; Chattopadhyay, S. K.; Umarye, J. D.; Tetrahedron Lett. 1999, 40, 4881.

29. Srikrishna, A.; Ramasastry, S. S. V.; Tetrahedron Lett. 2006, 47, 335; Srikrishna, A.; Dethe, D. H.; Tetrahedron Lett. 2005, 46, 3381 .

30. Sakagami, M.; Muratake, H.; Natsume, M.; Chem. Pharm. Bull. 1994, 42, 1393.

31. Solladié, G.; Gehrold, N.; Maignan, J.; Tetrahedron: Asymmetry 1999, 10, 2739.

32. Chiba, S.; Kitamura, M.; Narasaka, K.; J. Am. Chem. Soc. 2006, 128, 6931; Asao, N.; Lee, S.; Yamamoto, Y.; Tetrahedron Lett. 2003, 44, 4265 .

33. Meulemans, T. M.; Stork, G. A.; Jansen, B. J. M.; de Groot, A.; Tetrahedron Lett. 1998, 39, 6565.

34. Verstejen-Haaksma, A. A.; Swarts, H. J.; Jansen, B. J. M.; de Groot, A.; Tetrahedron 1994, 50, 10073.

35. Sandborn, L. T.; Org. Synth. 1941, 1, 340.

36. Vashchenko, V.; Kutulya, L.; Krivoshey, A.; Synthesis 2007, 2125 . 